\title{
Inland dunes on the abandoned bed of Glacial Lake Chicago indicate eolian activity during the Pleistocene-Holocene transition, southwestern Michigan, USA
}

\author{
Patrick M. Colgan ${ }^{\mathrm{a} *}$, William H. Amidon ${ }^{\mathrm{b}}$, Sara A. Thurkettle ${ }^{\mathrm{a}}$ \\ a Department of Geology, Grand Valley State University, Padnos Hall of Science, 1 Campus Drive, Allendale, MI 49401, United States \\ ${ }^{\mathrm{b}}$ Department of Geology, Middlebury College, McCardell Bicentenial Hall, 276 Bicentennial Way, Middlebury, VT 05753, United States
}

(ReCEIVEd March 10, 2016; AcCEPTED December 1, 2016)

\begin{abstract}
Inland dune fields have recently emerged as a source of data for reconstructing paleoenvironments and climate in the western Great Lakes region of North America during the Pleistocene-Holocene transition. We employ optically stimulated luminescence (OSL) methods, radiocarbon ages, soils, and landform relationships to determine the age of inland dunes in Ottawa County, Michigan. These dunes rest on the abandoned bed of Glacial Lake Chicago, which is thought to have been exposed after $\sim 13.6 \mathrm{ka}$. OSL analyses from two inland dunes yield ages ranging from $13.3 \pm 1.1$ to $11.6 \pm 0.9 \mathrm{ka}$ (uncertainty $=2 \boldsymbol{\sigma}$ ). Fine sand in the parabolic dunes suggests deflation of exposed glaciolacustrine nearshore sand by northwesterly and westerly winds. These new data add to a growing number of studies that demonstrate widespread eolian activity in the western Great Lakes region during the Pleistocene-Holocene transition. OSL ages from dune fields in the western Great Lakes indicate peak eolian activity and dune stabilization occurred during or following the Younger Dryas and Preboreal events. Northwesterly and westerly winds suggest the limited effect of hypothesized easterly anticyclonic winds during the Pleistocene-Holocene transition. Rapidly changing climate and newly deglaciated surfaces provided an ideal environment for dune formation.
\end{abstract}

Keywords: Early Holocene; Late Pleistocene; Wisconsin Episode; Younger Dryas; Bølling-Allerød; Eolian; Optically stimulated luminescence; Radiocarbon; Glacial Lake Chicago; Michigan

\section{INTRODUCTION}

Late Pleistocene and Holocene eolian dunes in the western Great Lakes region of North America (Fig. 1A) are increasingly being used as a source of evidence for paleolake levels, glaciofluvial sedimentation events, climate changes, and past atmospheric circulation patterns. A growing number of studies hypothesize causal links between coastal dune activity and lake level changes (e.g., Arbogast and Loope, 1999; Loope and Arbogast, 2000; Arbogast et al., 2002a, 2010; Hansen et al., 2003, 2006, 2010; Blumer et al., 2012). Newly constructed inland dune chronologies have been recently utilized to infer eolian activity during the PleistoceneHolocene transition and early Holocene (Arbogast et al., 2002b, 2015; Rawling et al., 2008; Loope et al., 2010; Miao et al., 2010; Campbell et al., 2011; Kilibarda and Blockland,

*Corresponding author at: Department of Geology, Grand Valley State University, Padnos Hall of Science, 1 Campus Drive, Allendale, MI 49401, United States. E-mail address: colganp@gvsu.edu (P.M. Colgan).
2011; Loope et al., 2012). Coastal spits and dunes have also been employed to reconstruct paleowind patterns associated with a hypothesized anticyclone, which may have persisted over a retreating Laurentide Ice Sheet (Krist and Schaetzl, 2001; Kilibarda and Blockland, 2011; Vader et al., 2012). Nearly all of these studies use optically stimulated luminescence (OSL) to estimate the age of eolian sediments as this method is well suited to quartz-dominated loess and dune sand.

Two distinct populations of dunes have been recognized in Michigan as a result of previous studies: coastal dunes and inland dunes (Arbogast et al., 1997; Arbogast and Jameson, 1998; Arbogast, 2009). Coastal dunes are found along the shores of the western Great Lakes (Fig. 1B) and are primarily middle to late Holocene phenomena, related to coastal evolution and lake level changes following the Nipissing transgression (e.g., Arbogast and Loope, 1999; Arbogast et al., 2002a, 2010; Hansen et al., 2010). Coastal dunes are large parabolic dunes up to $50 \mathrm{~m}$ in relief, and sometimes perched up to $100 \mathrm{~m}$ above the current lake 


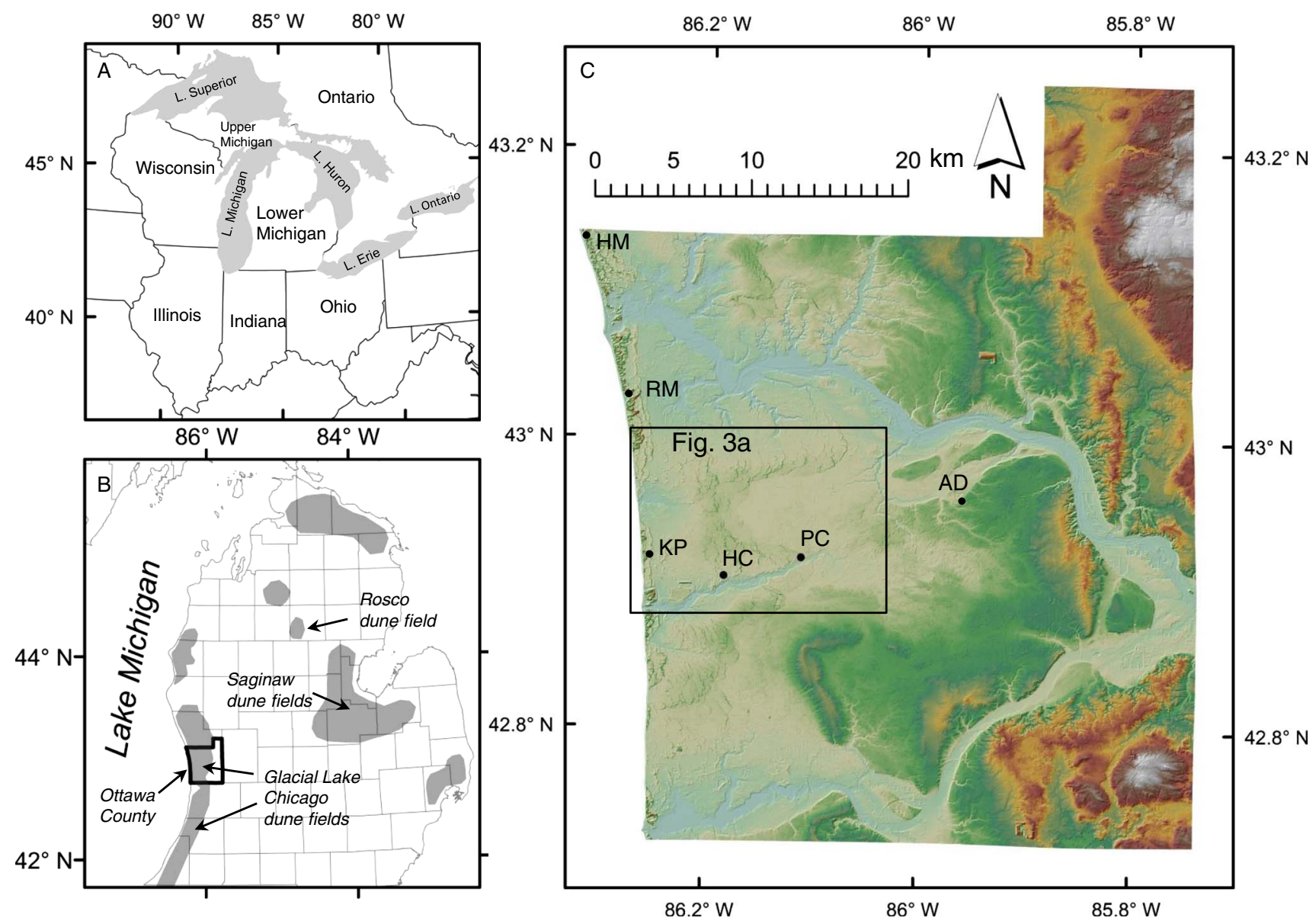

Figure 1. (color online) (A) Location map of the western Great Lakes region of North America. (B) Location of the study area in Ottawa County, Michigan, and areas of inland dunes in Lower Michigan (shaded areas are after Arbogast and Jameson [1998]). (C) Shaded relief image derived from a 2004 LIDAR (light detection and ranging) digital elevation model of Ottawa County, Michigan. Location of our two optically stimulated luminescence (OSL) sample sites at Hemlock Crossing Park (HC) and Pigeon Creek Park (PC). Previous radiocarbon and OSL dune studies at Rosy Mound Natural Area (RM) and Hoffmaster State Park (HM). Coastal dune sediment samples from Kirk Park (KP). Allendale delta sediment samples from near Allendale, Michigan (AD).

surface (Arbogast, 2009). A back dune complex of lower-relief parabolic dunes and dune ridges is also present up to a few kilometers inland (e.g., Arbogast and Loope, 1999; Arbogast et al., 2002a, 2010; Hansen et al., 2010). Radiocarbon and OSL analyses for coastal dunes in Lower Michigan yield ages less than $\sim 6.0 \mathrm{ka}$, although a few dunes have produced slightly older ages (Hansen et al., 2010).

Dunes are also found on abandoned outwash and lacustrine plains, well inland from coastal dunes (Fig. 1B). Inland dunes have much lower relief $(\sim 10 \mathrm{~m})$ than coastal dunes and are part of extensive sand sheets, which cover abandoned outwash and lacustrine plains (e.g., Arbogast et al., 1997, 2015; Arbogast and Jameson, 1998; Loope et al., 2010, 2012). Only three OSL studies estimate the age of inland dunes on abandoned outwash and glacial lacustrine plains in Michigan, and these studies have produced late Pleistocene and early Holocene ages for these dunes (Loope et al., 2010, 2012; Arbogast et al., 2015). Notably, there are no OSL studies for inland dunes found on the former bed of Glacial Lake
Chicago in western Lower Michigan (Fig. 1B), even though inland dunes are common in this area and cover an estimated area greater than $200 \mathrm{~km}^{2}$ in Ottawa County, Michigan, alone (Fig. 1C).

In this article, we present the first OSL ages for inland dunes on the abandoned bed of Glacial Lake Chicago in western Lower Michigan (Fig. 1C). Our new ages demonstrate that these inland dunes were active during the latest part of the Bølling-Allerød and the subsequent Younger Dryas and Preboreal events immediately following final drainage of Glacial Lake Chicago after $\sim 13.6 \mathrm{ka}$ (Larson, 2011). Our OSL ages add to a growing number of OSL studies of inland dune fields in the western Great Lakes region and demonstrate a peak in eolian activity during, and slightly after, the end of the Younger Dryas event. Additionally, all of these studies demonstrate northwesterly or westerly winds and do not support the hypothesis of easterly anticyclonic winds along the retreating ice margin of the Laurentide Ice Sheet during the Pleistocene to Holocene transition. 


\section{Geomorphic setting of inland dunes}

Landforms and sediments in Ottawa County, Michigan, are predominately late Pleistocene glaciolacustrine plains of gravelly nearshore sand, moraines and till plains composed of silt-rich diamicton, and valley trains of sand and gravel between end moraines (Fig. 2). Wisconsin Episode (formerly late Wisconsinan) and older glaciogenic sediments vary from $\sim 10$ to $>100 \mathrm{~m}$ thick and cover late Mississippian bedrock of shale, sandstone, and limestone (Colgan et al., 2015). In eastern Ottawa County, there are end moraines, till plains, uplands, and associated valley trains of the Valparaiso and Lake Border moraine systems (Fig. 2) formed during the Crown Point Phase 18,200 to 16,800 cal yr BP (Leverett and Taylor, 1915; Curry et al., 2011; Larson, 2011). The western half of Ottawa County is a sandy lacustrine plain abandoned by Glacial Lake Chicago after $\sim 13,600$ yr BP (Larson, 2011) and subsequently modified by eolian, fluvial, and coastal processes (Figs. 1C and 2).

Inland dunes on the abandoned bed of Glacial Lake Chicago are covered in forest where not disturbed or heavily modified by humans. Before European settlement in the early 1800s, the area around Pigeon River in western Ottawa County (Fig. 3A) was composed of sandy uplands, covered by a drymesic northern forest of Pinus strobus, Quercus albus, Quercus rubra, Acer rubrum, Fagus grandifolia, Prunus serotina, Populus grandidentata, and Tsuga canadensis. The river valleys were dominated by marsh, wet meadows, floodplain forests, and hardwood conifer swamps (William Martinus \& Associates, 2000). Most of the inland dunes in Ottawa County show evidence of wind reworking and human disturbance. Small blowouts in the dunes indicate deflation following intensive logging in the nineteenth century. Heavily disturbed dune areas were planted with Pinus resinosa by the Civilian Conservation Corp in the 1930s (William Martinus \&
Associates, 2000). These eroded, inland dune sites are easy to identify because soil profiles are absent in blowouts, and downwind areas are buried in eroded soils, which commonly bury preserved soil profiles.

\section{Glacial and postglacial lakes of the Lake Michigan basin}

Glacial Lake Chicago occupied the Lake Michigan basin between $\sim 17,000$ and $\sim 13,600$ cal yr BP (Table 1, Fig. 2C) based on the existing calibrated radiocarbon chronology (Larson and Schaetzl, 2001; Kincare and Larson, 2009; Curry et al., 2011; Larson, 2011). At its highest levels (Glenwood and Calumet Phases), Glacial Lake Chicago drained southward through an outlet near Chicago into the Mississippi drainage basin (Bretz, 1951). The historical mean level of modern Lake Michigan is $\sim 176.6 \mathrm{~m}$ above mean sea level (amsl). Glacial Lake Chicago rose to a maximum level of between 202 and $204 \mathrm{~m}$ amsl in the study area (Fig. 2C) based on the highest elevations of the Allendale and Zeeland deltas (Fig. 2C) as mapped by Leverett and Taylor (1915). The Glenwood I level (Table 1) occurred during and after the retreat of the Lake Michigan lobe following the Crown Point Phase after $\sim 17,000 \mathrm{cal}$ yr BP (Curry et al., 2011; Larson, 2011). The Mackinaw Phase ( 16,500 to $15,800 \mathrm{cal}$ yr BP) marked a period of low lake level when ice retreated north opening a spillway in the Straits of Mackinaw (Hansel et al., 1985; Hansel and Mickelson, 1988). The Lake Michigan lobe then readvanced during the Port Huron Phase $(\sim 15,800$ to $15,200 \mathrm{cal}$ yr BP) as far south as Grand Haven, Michigan, and causing Glacial Lake Chicago to rise again to the Glenwood II level (Larson, 2011). The Calumet level of Glacial Lake Chicago (Table 1) occurred during the Two Rivers Phase $\sim 15,200$ to $\sim 13,600$ cal yr BP (Larson, 2011).
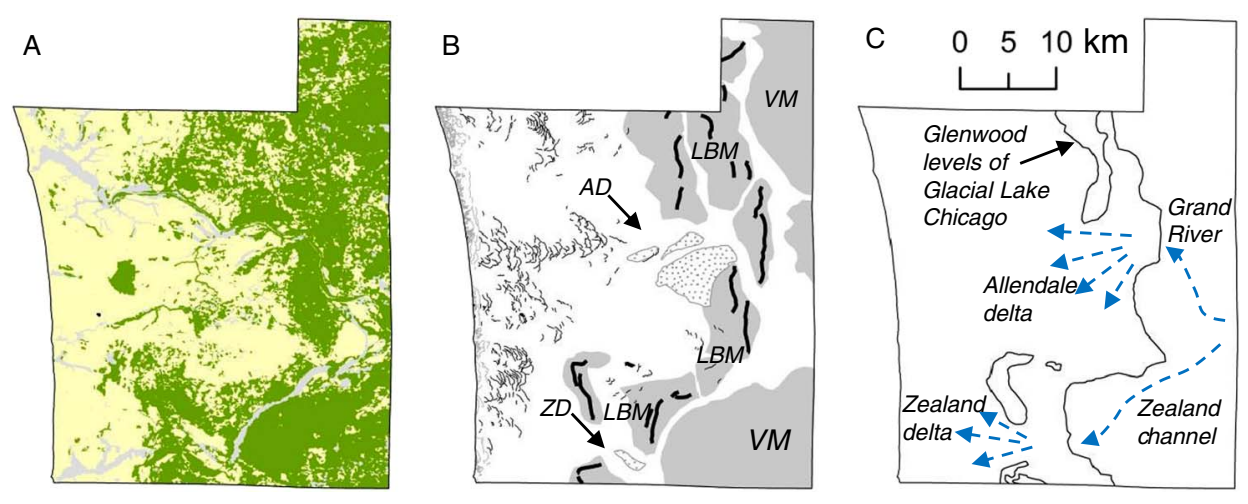

Figure 2. (color online) (A) Map of soil textures of parent materials in Ottawa County. Sand textured soils are shown in yellow, and loam textured soils are shown in green (data are from the US Department of Agriculture's SSURGO Database-https://www.nrcs.usda.gov/wps/portal/ nrcs/detail/soils/survey/?cid=nrcs142p2_053627, accessed March 1, 2016). (B) Landforms of Ottawa County, Michigan. Gray areas are end moraines and till plains of the Lake Border (LBM) and Valparaiso (VM) moraine systems, which were deposited by the Lake Michigan lobe as it advanced out of Lake Michigan basin and flowed to the east and southeast (distal sides of moraines are on the east). Thick dark lines are moraine ridge crests. Thin black lines are inland dune crests, and thin gray lines are coastal dune crests. Allendale delta (AD) and Zeeland delta (ZD) sediments are shown in stippled pattern. (C) The highest shoreline of Glacial Lake Chicago during the Glenwood I and II levels is shown with a dark line based on the descriptions of Leverett and Taylor (1915), and highest elevations of the Allendale ( 204 m amsl) and Zeeland ( $\sim 202 \mathrm{~m}$ amsl) deltas. (For interpretation of the references to color in this figure legend, the reader is referred to the web version of this article.) 

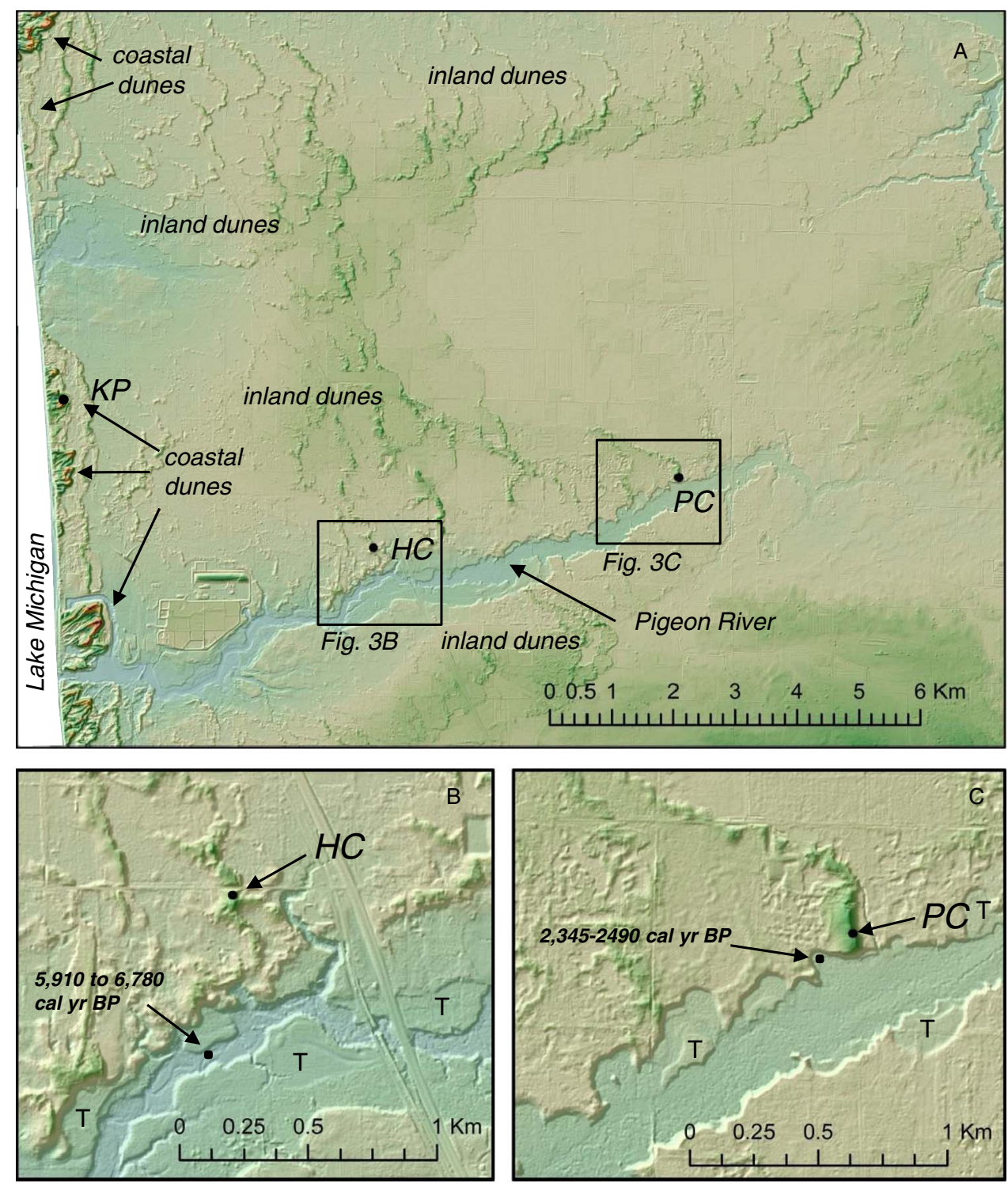

Figure 3. (color online) (A) Map showing sampling sites for optically stimulated luminescence (OSL) and radiocarbon analyses. Hemlock Crossing County Park (HC) and Pigeon Creek County Park (PC). (B) Hemlock Crossing OSL site (42 ${ }^{\circ} 55.2624^{\prime}$ N; 86 $9.1608^{\prime}$ W; World Geodetic System of 1984 [WGS 84]). (C) Pigeon Creek Park OSL site (4255.9110' N; 86 5.5494' W; WGS84 = World Geodetic System of 1984). OSL sample sites are shown with black circles, and radiocarbon samples from vibracores in alluvial are shown with black squares. "T" indicates Lake Nipissing age terraces along the Pigeon River.

After $\sim 13,600 \mathrm{cal}$ yr BP, Glacial Lake Chicago ceased to exist as ice retreated north and the lake merged with early Glacial Lake Algonquin to form the larger main Algonquin Phase at a level probably lower than the present lake level in the study area (Larson, 2011).

Following Glacial Lake Algonquin, postglacial Lake Chippewa formed at a much lower level (as low as $\sim 70-90 \mathrm{~m}$ amsl) because of opening of drainage paths to the north and east (Larson and Schaetzl, 2001; Kincare, 2007). The lowest level of Lake Chippewa is thought to have occurred at $\sim 11,000$ cal yr BP (Kincare, 2007). As a result of this large drop in lake level, rivers in western Michigan incised deeply in response to lowered base levels (Kincare, 2007). The Grand, Pigeon, and Macatawa Rivers all have morphologies and valley fills consistent with this hypothesis. Lake level then rose gradually because of rebound of the outlet of Lake Chippewa to the north and east, finally reaching high stands of Lake Nipissing at $\sim 5500$ and $\sim 4500$ cal yr BP (Baedke and Thompson, 2000). Lake Nipissing probably reached its highest elevation in the study area of $\sim 186$ to $187 \mathrm{~m}$ masl based on a prominent wave-cut cliff near Holland, Michigan, and well-developed stream terraces along the Grand, Pigeon, and Macatawa Rivers.

\section{Previous dune research in western Michigan}

Coastal dunes have been well studied in and adjacent to Ottawa County, Michigan. Arbogast and Loope (1999) examined coastal dunes at Rosy Mound Natural Area (Fig. 1C) 
Table 1. Glacial and postglacial lake levels in the Lake Michigan basin.

\begin{tabular}{|c|c|c|c|}
\hline $\begin{array}{l}\text { Lake } \\
\text { name }\end{array}$ & $\begin{array}{l}\text { Lake level } \\
\text { phase }\end{array}$ & $\begin{array}{c}\text { Maximum } \\
\text { elevation }(\mathrm{amsl})^{\mathrm{a}}\end{array}$ & $\begin{array}{c}\text { Estimated } \\
\text { Age }(\text { cal yr BP })^{\mathrm{b}}\end{array}$ \\
\hline Glacial Lake Chicago & Glenwood I & $202-204$ & $17,000-16,500$ \\
\hline Lake Mackinaw $^{c}$ & Mackinaw & $<177$ & $16,000-15,800$ \\
\hline Glacial Lake Chicago & Glenwood II & $202-204$ & $15,800-15,200$ \\
\hline Glacial Lake Chicago $^{\mathrm{d}}$ & Calumet & 195 & $15,200-13,600$ \\
\hline Glacial Lake Algonquin $^{c}$ & Algonquin & $<177$ & $13,600-12,500$ \\
\hline Lake Chippewa $^{\mathrm{c}}$ & Chippewa & 70-90 & $11,000-9000$ \\
\hline Lake Nipissing & Nipissing I, II & $186-187$ & $5500-4500$ \\
\hline Lake Algoma & Algoma & 181 & $\sim 3000$ \\
\hline Lake Michigan & Michigan & 177 & 2500-present \\
\hline
\end{tabular}

a Our estimates of lake level elevations for Ottawa County based on sediments and landforms. amsl, above mean sea level.

${ }^{b}$ Age estimates for lake levels are from Kincare and Larson (2009), Larson (2011), and Baedke and Thompson (2000). Age range is possible time of lake level.

${ }^{\mathrm{c}}$ There is no evidence for these lakes in Ottawa County as both levels are thought to have been lower than current level of Lake Michigan (Kincare, 2007).

d The final phase of Glacial Lake Chicago (Calumet level) occurred after the Two Rivers-Onaway Phase estimated by Larson (2011) as occurring at $\sim 11,700{ }^{14} \mathrm{C}$ yr BP $(\sim 13,600 \pm 150$ cal yr BP).

in northwestern Ottawa County as part of a larger study of dunes along the eastern shoreline of Lake Michigan. They provided the first radiocarbon ages of buried soils to demonstrate that coastal dunes are post-Nipissing features younger than $\sim 6000 \mathrm{cal}$ yr BP. Coastal dunes have also been studied just south of Holland, Michigan, in northwestern Allegan County, and at P.J. Hoffmaster State Park (Fig. 1C) in northwestern Ottawa County and southwestern Muskegon County (Loope and Arbogast, 2000; Arbogast et al., 2002a; Hansen et al., 2003, 2006, 2010). The Holland dune complex contains active and inactive parabolic dunes up to $50 \mathrm{~m}$ high, and lower-relief inactive back dune ridges. These dunes produced calibrated radiocarbon and OSL ages varying from $\sim 0.3$ to $5.9 \mathrm{ka}$ (Hansen et al., 2010). The dune complex at Hoffmaster State Park (Fig. 1C) has a more varied assemblage of dune types with several overlapping generations of large active and inactive parabolic dunes, and several generations of overlapping back dune ridges (Hansen et al., 2010). OSL ages for these dunes produced ages from $\sim 0.3$ to $\sim 7.2 \mathrm{ka}$ (Hansen et al., 2010). Interestingly, the oldest OSL age at Hoffmaster State Park $(7.2 \pm 1.0 \mathrm{ka})$ was from a back dune ridge about $1 \mathrm{~km}$ inland from Lake Michigan. Another anomalously old OSL age $(10.5 \pm 1.4 \mathrm{ka})$ was reported from a large parabolic dune in Warren Dunes State Park, Indiana (Hansen et al., 2010). Both of these ages suggest that pre-Nipissing age dunes may have been reworked and later buried during the late Holocene. These previous studies confirm that coastal dunes in the study area are Nipissing or younger in age $(<6 \mathrm{ka})$. None of these previous studies discuss or provide ages for the small inland dunes that we focus on in this article.

\section{MATERIALS AND METHODS}

We carefully selected our two inland dune OSL sampling sites (Figs. 3 and 4) based on them having a preserved dune crest and soil profiles suggesting long-term stability. Finding suitable OSL sampling sites was facilitated by use of a digital elevation model (DEM) derived from LIDAR (light detection and ranging) data collected by Ottawa County, Michigan, in 2004. The DEM has a horizontal resolution of $\sim 3 \mathrm{~m}$ and a vertical accuracy of $\sim 0.1 \mathrm{~m}$. The DEM greatly enhanced our ability to pick suitable OSL sampling sites that were not eroded or reworked. Both of the dunes we sampled have preserved dune crests with gentle windward sides and steeper lee sides (Figs. 3 and 4). The sample sites are covered in forest. Most importantly, both dune crests have well-developed $\mathrm{O} / \mathrm{A} / \mathrm{E} / \mathrm{B}$ horizons with sesquioxides and translocated humus (Bhs)/C soil horizons with sola depths of $\sim 60$ to $70 \mathrm{~cm}$ developed on their dune crests (Figs. 5 and 6). Additionally, ground-penetrating radar (GPR) profiles run across the dune crest at the Pigeon Creek OSL sampling site indicate eastwarddipping slip faces in the dune (Fig. 7). The preserved soil profiles, history of forest cover during the Holocene, and eastward-dipping slip faces in a GPR profiles, suggest that our OSL sampling sites have been stable during the Holocene.

Samples for OSL dating were collected in soil pits roughly $1.5 \mathrm{~m} \times 1.5 \mathrm{~m}$ and $1.7 \mathrm{~m}$ deep (Fig. 5). All of our OSL samples were taken from below $1.2 \mathrm{~m}$ depth, below the sola depth and root zone that extends to $\sim 0.6-0.7 \mathrm{~m}$. Aluminum sample tubes were driven into the pit wall and then carefully excavated. Tube ends were packed with Styrofoam to avoid sample movement during transport. One sample (HC-3) was collected below the bottom of the pit using a bucket auger, $\sim 10 \mathrm{~cm}$ in diameter, in order to obtain a deeper sample $(\sim 2.45 \mathrm{~m}$ depth). A sample tube was then driven into the bucket of the auger and then treated as described previously. Samples for moisture content were collected from within $\sim 20 \mathrm{~cm}$ of the tube samples. Soil profiles were described for horizon thickness, organic matter, texture, Munsell soil color, and any special characteristics (Buol et al., 1989). Sediment 


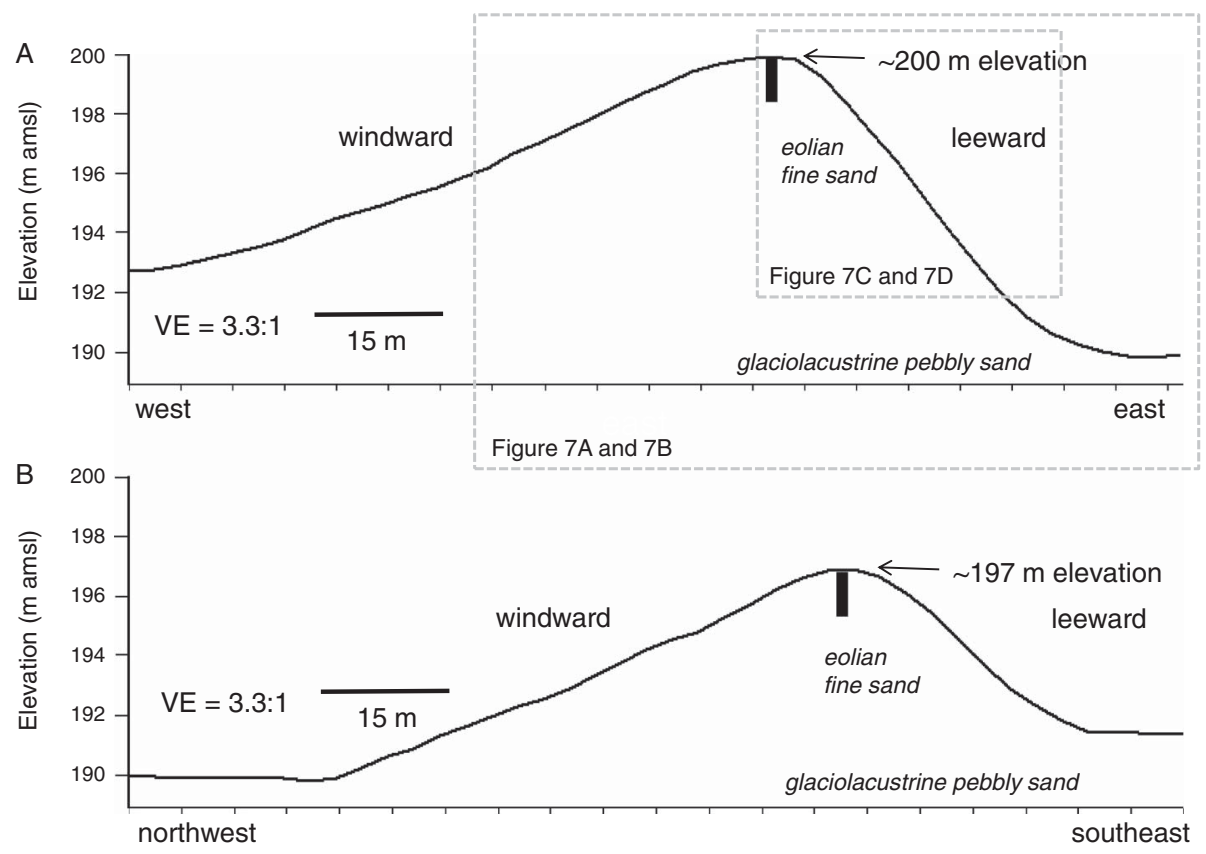

Figure 4. Topographic profiles of dune sample sites at Pigeon Creek Park (A) and Hemlock Crossing Park (B). Profiles run across the dune crest where soil pits for optically stimulated luminescence samples were dug (black bars). Note that the total relief of each dune is less than $10 \mathrm{~m}$. Vertical exaggeration is $\sim 3.3: 1$ in both profiles. The dashed boxes are approximate coverages of the two groundpenetrating radar profiles shown in Figure 7.

grain-size distributions were determined using dry-sieving methods (Lewis and McConchie, 1994). We did not wash samples before sieving because they contained less than $1 \%$ fines (Table 2). Grain-size statistics were calculated using GRADISTAT v. 8.0 (Blott and Pye, 2001). When citing ages, we use "ka" for all OSL age dates and "cal yr BP" for ages estimated using the radiocarbon method or the existing radiocarbon chronology.

\section{OSL laboratory methods}

OSL analyses were performed at the Middlebury College Luminescence Laboratory. Full analytical details are available in the Supplementary Materials. All luminescence samples were processed under a $589 \mathrm{~nm}$ sodium vapor lamp further filtered with a Lee 101 filter. Following overnight treatments in $10 \% \mathrm{HCl}$ and bleach, modal size fractions (165 to $250 \mu \mathrm{m})$ of each luminescence sample underwent multiple density separations in solutions of lithium heteropolytungstate to obtain a pure quartz fraction $(\rho=2.58$ to $2.66 \mathrm{~g} / \mathrm{mL})$. Quartz samples then underwent two 30-minute etches in concentrated $\mathrm{HF}$ before a final 30-minute etching in concentrated $\mathrm{HCl}$. All samples were then hand-rubbed and resieved through an $80 \mu \mathrm{m}$ cloth to break apart low-quality fragments and ensure measurement of intact, high-quality grains.

Signals were measured on small aliquots $(\sim 20$ to 100 grains per disk) following the standard single aliquot regenerative (SAR) procedure (Murray and Wintle, 2000). Strict rejection criteria were applied, including $10 \%$ rejection thresholds for the recycling, recuperation, and test dose repeatability tests. Postanalysis IR checks were used to verify sample purity. Fast ratios suggest that shine-down curves were dominated by the fast component and a rejection threshold of aliquots with fast ratios less than 12 (Durcan and Duller, 2011). Early background correction was employed to further minimize the potential impact of slow and medium components (Cunningham and Wallinga, 2010). This involved subtraction of the mean signal over the 4- to 5-second interval from the mean signal over the 0- to 0.5-second interval. Equivalent dose $\left(D_{e}\right)$ for individual disks was estimated using a quadratic fit to all of the measured SAR steps. Burial dose for samples was estimated using the central age model, which is justified given that overdispersion was always $<20 \%$, skew was $<1$, and kurtosis was between -1 and 1 (Galbraith et al., 1999).

Dose rates were calculated from the inductively coupled plasma mass spectrometry (ICP-MS) bulk geochemistry of representative samples collected within a $20 \mathrm{~cm}$ radius of each sample's location (Guerin et al., 2011). Chemical analyses were performed by ALS Minerals in Reno, Nevada, using a lithium metaborate fusion followed by ICP-MS analysis for both trace and major elements. Dose rates and ages were then computed using the online DRAC (dose rate and age calculator) v. 1.1 (Durcan et al., 2015). Water contents were computed on samples collected from a $20 \mathrm{~cm}$ sphere using a mass difference calculation after drying in an oven for 2 days at $60^{\circ} \mathrm{C}$ (wet weight - dry weight at room temperature). 

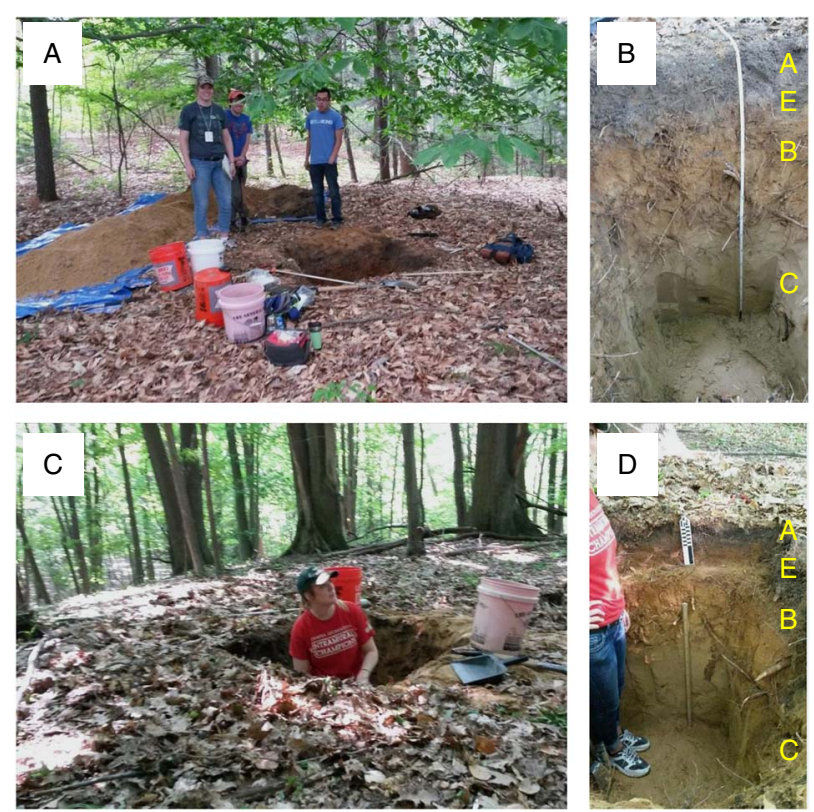

Figure 5. (color online) Photographs of the dune sampling sites and soil pits. (A) Hemlock Crossing sampling site looking to the southwest along the crest of the dune. The leeward side of the dune is to the left, and the windward side is to the right. (B) Soil pit at Hemlock Crossing Park site (northwest pit wall). (C) Pigeon Creek sampling site looking to the southeast; the leeward side of the dune is visible in the background sloping to the east. (D) Soil pit and profile at Pigeon Creek Park (north pit wall). The soil master horizons are labeled with $\mathrm{A}, \mathrm{E}, \mathrm{B}$, and $\mathrm{C}$.

\section{RESULTS}

\section{Dune distribution, morphology, and sedimentology}

Inland dunes in the study area occur as far as $\sim 15 \mathrm{~km}$ inland from Lake Michigan (Figs. 1C and 3A). The highest elevation of the lacustrine plain on which inland dunes are developed is $\sim 200 \mathrm{~m}$ amsl ( $23 \mathrm{~m}$ above current level of Lake Michigan), and the lowest elevation is $\sim 185 \mathrm{~m}$ amsl ( $\sim 8 \mathrm{~m}$ above lake level). The highest inland dunes have a relief of $\sim 10 \mathrm{~m}$ and vary from $\sim 50$ to $100 \mathrm{~m}$ wide with dune ridges commonly traceable for more than a kilometer (Fig. $3 \mathrm{~A})$. Inland dune morphologies are classified as compound and complex parabolic dunes (Cooke et al., 1993). The dune sampled at Hemlock Crossing Park (Fig. 3B) is part of a compound parabolic dune with arms oriented to the northwest $\left(\sim 340^{\circ}\right)$. The dune at Pigeon Creek is part of a rakelike compound parabolic dune that is oriented to winds coming from the west (Fig. 3C). Both of the inland dunes we sampled are part of an extensive sand sheet, and a series of imbricate ridges so must have formed and stabilized at roughly the same time (Fig. 3A).

The two inland dunes we sampled for OSL dating are composed of fine sand (Table 2) with a mean $D_{50}$ of $209 \pm 19 \mu \mathrm{m}$, and with fines much less than $1 \%(\mathrm{n}=6$, 2 -sigma). Inland dune sand is significantly finer than coastal dune samples collected just west of our sites (Fig. 1C,

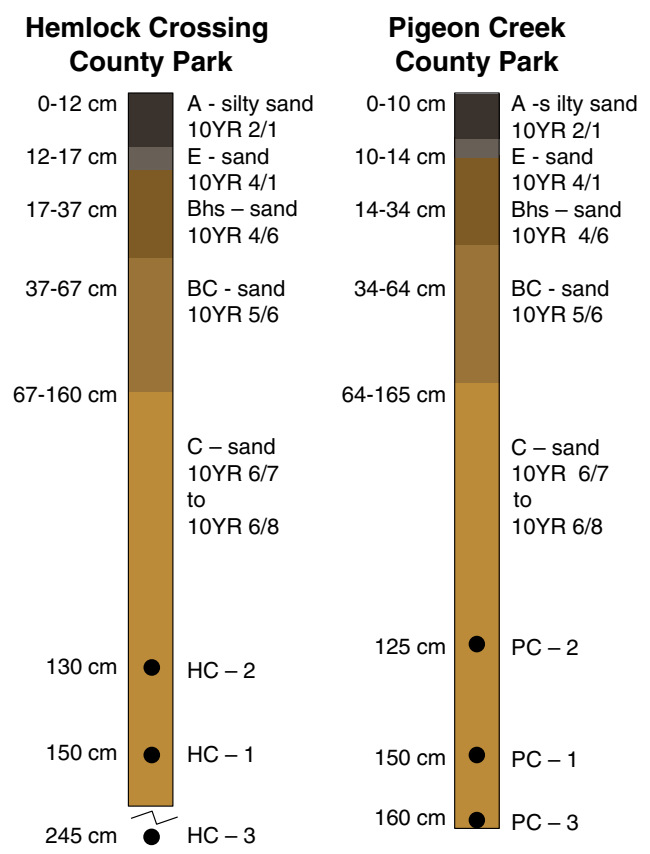

Figure 6. (color online) Graphic soil profiles from Hemlock Crossing and Pigeon Creek Parks on dune crest optically stimulated luminescence (OSL) sampling sites. Both soils are weakly developed Spodosols. Black dots indicate depths where OSL samples were taken. Bhs, B horizons with sesquioxides and translocated humus.

site KP) on the crests of two large parabolic dunes at Kirk Park $\left(D_{50}\right.$ of $\left.270 \pm 28 \mu \mathrm{m}, \mathrm{n}=6\right)$. Sediments of the Allendale delta deposited in Glacial Lake Chicago in the area (Fig. 1C, site AD; Table 2) are composed of moderately to poorly sorted, gravelly medium sands with a mean $D_{50}$ of $294 \pm 17 \mu \mathrm{m}(\mathrm{n}=3)$. This and other lacustrine units cover large areas of Ottawa, Muskegon, Allegan, and other coastal counties in western Michigan. The sediment has been mapped and interpreted as nearshore lacustrine sand and gravel deposited during the Glenwood and Calumet levels of Glacial Lake Chicago (Leverett and Taylor, 1915; Martin, 1955; Farrand, 1982). The lacustrine sand and gravel varies from a few meters thick to well over $20 \mathrm{~m}$ thick based on mapping and water well records in Ottawa and Muskegon Counties. At depth, offshore silt and clay beds are commonly interbedded with or underlie the lacustrine sand and gravel (Colgan and Stark, 2005a, 2005b; Colgan and Tort, 2006; Colgan et al., 2015). Seven near-surface samples of Glacial Lake Chicago nearshore sediment collected in southeastern Muskegon County (Table 2) are moderately to poorly sorted, gravelly medium sand and have a $D_{50}$ of $307 \pm 26 \mu \mathrm{m}(\mathrm{n}=7)$.

No sedimentary structures or unconformities below the base of the sola were observed in either of the two soil pits dug during OSL sampling. Slip faces have been observed in sand pits in other inland dunes in the study area if the bedding is dried out and etched by winds, but it is very difficult to see these slip faces in fine eolian sand, especially when moist and in a small exposure such as a hand-dug soil pit. A GPR profile run across the dune through our sampling site at Pigeon 


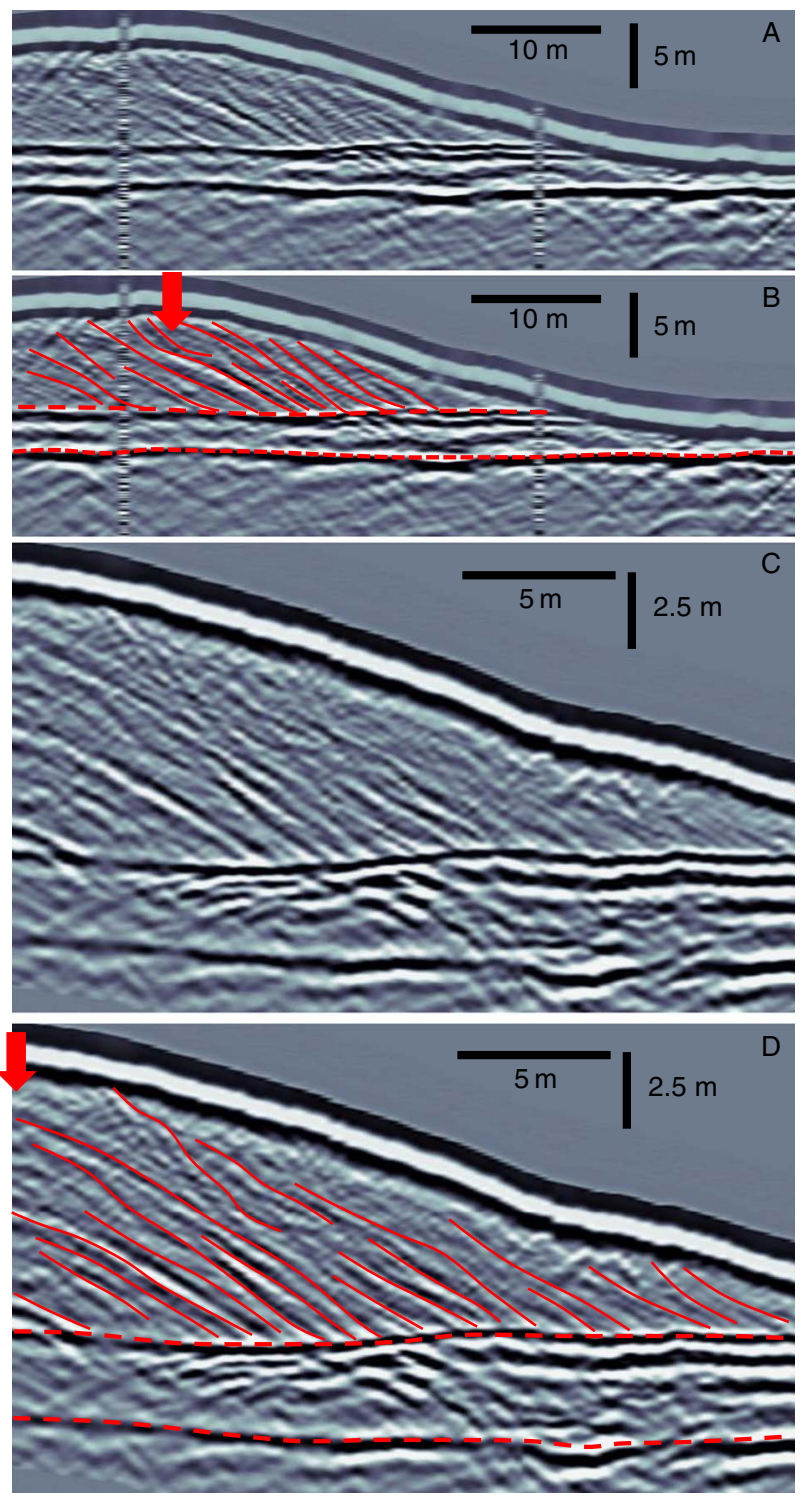

Figure 7. (color online) Ground-penetrating radar (GPR) reflection profiles of the inland dune at Pigeon Creek County Park. These profiles run west to east, the same as the dune profile in Figure 4A. The profile was obtained using a PulseEkko 100 system. A common midpoint offset survey estimated wave velocity of $0.132 \mathrm{~m} / \mathrm{ns}$ for the dune sand at the site. (A) GPR profile across dune crest using a $50 \mathrm{MHz}$ frequency antennae with a transmitter receiver separation of $2 \mathrm{~m}$, step size of $0.5 \mathrm{~m}$, and stacking of 128 times; total length of profile is $60 \mathrm{~m}$, and total depth is $\sim 20 \mathrm{~m}$. (B) Our interpretation of the profile in panel A. Red dashed lines mark the interpreted contact of the dune sediment with underlying Glacial Lake Chicago nearshore sediment (highest dashed line) and the groundwater table (lowest dashed line). (C) GPR profile obtained with a $100 \mathrm{MHz}$ frequency antennae with a transmitter receiver separation of $1 \mathrm{~m}$, step size of $0.25 \mathrm{~m}$, and stacking of 128 times; total length of profile is $25 \mathrm{~m}$, and total depth is $\sim 17 \mathrm{~m}$. (D) Our interpretations of buried slip faces in the dune (red solid lines). Interpretations of sediment and groundwater table are the same as in panel B. (For interpretation of the references to color in this figure legend, the reader is referred to the web version of this article.)
Creek Park shows dipping reflectors that we interpret as slip faces (Fig. 7). Two other prominent reflectors at depth in the profiles are interpreted as the contact between dune sand and gravelly nearshore lacustrine sand, and the underlying water table (Fig. 7).

\section{Soil profiles developed on inland dunes}

Soil horizons are present on the inland dunes of western Ottawa County where they are not eroded by blowouts or heavily modified by humans. Many inland dunes are extensively modified by small blowouts that have completely eroded all soil horizons and left depressions from 1 to $5 \mathrm{~m}$ deep and from 10 to $50 \mathrm{~m}$ in diameter (Fig. 3B and C). Most of the inland dunes of Hemlock Crossing Park and Pigeon Creek Park are mapped as "blown out land" in the Soil Survey of Ottawa County, Michigan (US Department of Agriculture, Soil Conservation Service, 1972), even though preserved soils or buried soils are present in numerous locations. Where soils are preserved or buried by blown sand, soils probably correspond to those of the Rubicon Series. Soil profiles in these areas can be classified as Inceptisols or Spodosols with thin $\mathrm{O}, \mathrm{A}$, and $\mathrm{E}$ horizons over weak $\mathrm{B}$ horizons $(\mathrm{Bw})$ or spodic horizons (Bhs) and sometimes contain ort stones developed in the upper part of the B horizon. Figure 6 shows the soil profiles described in the OSL sampling pits at Hemlock Crossing and Pigeon Creek Parks on dune crests. At both sample sites, the soil profiles on the dune crests were $\mathrm{O} / \mathrm{A} / \mathrm{E} / \mathrm{Bhs} / \mathrm{BC} / \mathrm{C}$, with total sola thickness of $\sim 60$ to $70 \mathrm{~cm}$.

\section{Radiocarbon ages of Pigeon River valley alluvium}

Table 3 lists radiocarbon ages from buried organic beds in alluvium filling the Pigeon River valley. Four calibrated accelerator mass spectrometry (AMS) ages vary in age from 5910 to $6780 \mathrm{cal}$ yr BP (2-sigma range for four ages; Colgan and Stevens, 2016). These samples were collected in a series of vibracores taken across the valley and are from depths ranging from 2.5 to $2.8 \mathrm{~m}$ below the current floodplain surface (Fig. 3). An additional AMS radiocarbon age was obtained from alluvium sample in a vibracore recovered near the dune sample site at Pigeon Creek Park (Fig. 3). This wood sample is from a depth of $2.3 \mathrm{~m}$ and produced a 2-sigma calibrated age of 2345 to 2490 cal yr BP (Table 3 ).

\section{OSL ages of dune sediments}

Table 4 lists the OSL ages for the six dune samples taken from two sites. The ages (Fig. 8) are well clustered and range from $11.6 \pm 0.9$ to $13.3 \pm 1.1 \mathrm{ka}$ (2-sigma). The oldest OSL age is from a depth of $2.45 \mathrm{~m}$, from the dune at Hemlock Crossing Park. The youngest OSL age is from Pigeon Creek Park from a depth of $1.50 \mathrm{~m}$. All of the ages are within 2-sigma uncertainty of one another, although the mean age of sample HC-3 $(13.3 \pm 1.1 \mathrm{ka})$ is slightly older than the other five samples (Fig. 6). Although not significant at the 2-sigma 
Table 2. Texture data for eolian and glaciolacustrine sediments in Ottawa and Muskegon Counties, Michigan.

\begin{tabular}{|c|c|c|c|c|c|c|c|c|c|c|c|c|}
\hline $\begin{array}{l}\text { Sample } \\
\text { number }\end{array}$ & $\begin{array}{l}\text { Depth } \\
(\mathrm{cm})\end{array}$ & $\begin{array}{c}\text { Mean } \\
(\mu \mathrm{m})\end{array}$ & $\begin{array}{l}D_{10} \\
(\mu \mathrm{m})\end{array}$ & $\begin{array}{c}D_{90} \\
(\mu \mathrm{m})\end{array}$ & Sort $^{\mathrm{a}}$ & $\begin{array}{l}\mathrm{gr} \\
\%\end{array}$ & $\begin{array}{c}\mathrm{vcs} \\
\%\end{array}$ & $\begin{array}{l}\mathrm{cs} \\
\%\end{array}$ & $\begin{array}{c}\mathrm{ms} \\
\%\end{array}$ & $\begin{array}{l}\text { fs } \\
\%\end{array}$ & $\begin{array}{l}\mathrm{vfs} \\
\%\end{array}$ & $\begin{array}{c}\text { Silt } \\
\%\end{array}$ \\
\hline \multicolumn{13}{|c|}{ Inland dune OSL samples from Hemlock Crossing and Pigeon Creek County, Ottawa County } \\
\hline HC-1 & 150 & 199.6 & 122.0 & 326.1 & 2.672 & - & - & 1.1 & 24.6 & 63.7 & 10.6 & 0.1 \\
\hline $\mathrm{HC}-2$ & 130 & 220.5 & 130.1 & 348.4 & 2.677 & - & - & 0.6 & 36.7 & 55.1 & 7.5 & 0.1 \\
\hline $\mathrm{HC}-3$ & 245 & 195.3 & 127.5 & 333.3 & 2.613 & - & - & 0.6 & 23.3 & 67.9 & 8.1 & 0.1 \\
\hline PC-1 & 150 & 219.2 & 121.4 & 337.2 & 2.567 & - & - & 0.9 & 34.3 & 57.6 & 7.1 & 0.1 \\
\hline PC-2 & 125 & 206.1 & 129.7 & 316.1 & 2.437 & - & - & 0.2 & 25.0 & 67.4 & 7.4 & 0.1 \\
\hline PC-3 & 160 & 211.9 & 127.9 & 337.4 & 2.638 & - & - & 0.9 & 30.7 & 59.9 & 8.5 & 0.0 \\
\hline Mean & - & 208.8 & 126.4 & 333.1 & 2.601 & - & - & 0.6 & 29.1 & 62.0 & 8.2 & 0.1 \\
\hline $2 \sigma$ & - & 18.8 & 6.9 & 20.1 & 0.164 & - & - & 0.4 & 10.3 & 9.6 & 2.3 & 0.0 \\
\hline \multicolumn{13}{|c|}{ Coastal dune samples from the crests of two large parabolic dunes at Kirk Park, Ottawa County } \\
\hline KP1-1 & 50 & 253.4 & 186.1 & 333.1 & 1.790 & - & 0.1 & 0.2 & 51.7 & 47.5 & 0.5 & 0.1 \\
\hline KP1-2 & 100 & 263.9 & 187.3 & 335.0 & 1.789 & - & - & - & 59.1 & 40.3 & 0.6 & 0.1 \\
\hline KP1-3 & 150 & 253.4 & 184.2 & 332.6 & 1.805 & - & - & 0.1 & 51.9 & 47.2 & 0.8 & 0.0 \\
\hline KP2-1 & 50 & 284.9 & 203.2 & 343.5 & 1.690 & - & - & 0.6 & 77.4 & 21.5 & 0.5 & 0.1 \\
\hline KP2-2 & 100 & 280.1 & 199.2 & 339.9 & 1.706 & - & - & 0.1 & 73.4 & 26.1 & 0.4 & 0.0 \\
\hline KP2-3 & 150 & 285.6 & 202.5 & 348.3 & 1.720 & - & - & 2.1 & 74.7 & 22.7 & 0.4 & 0.1 \\
\hline Mean & - & 270.2 & 193.8 & 338.7 & 1.750 & - & - & 0.5 & 64.7 & 34.2 & 0.5 & 0.1 \\
\hline $2 \sigma$ & - & 27.8 & 16.1 & 11.5 & 0.092 & - & - & 1.5 & 21.6 & 22.2 & 0.3 & 0.0 \\
\hline \multicolumn{13}{|c|}{ Allendale delta sediments from west of Allendale, Ottawa County } \\
\hline AD-1 & 150 & 284.7 & 139.1 & 536.0 & 3.854 & 2.0 & 0.7 & 9.0 & 60.8 & 24.7 & 1.7 & 1.1 \\
\hline $\mathrm{AD}-2$ & 150 & 305.4 & 252.2 & 611.6 & 2.425 & 2.8 & 0.9 & 15.0 & 73.2 & 7.1 & 0.5 & 0.6 \\
\hline $\mathrm{AD}-3$ & 150 & 291.8 & 148.0 & 547.9 & 3.703 & 0.8 & 1.9 & 9.9 & 66.9 & 19.5 & 0.6 & 0.6 \\
\hline Mean & - & 294.0 & 179.8 & 565.2 & 3.327 & 1.9 & 1.9 & 11.3 & 67.0 & 17.1 & 0.9 & 0.8 \\
\hline $2 \sigma$ & - & 17.2 & 102.7 & 66.4 & 1.282 & 1.6 & 1.2 & 5.3 & 10.1 & 14.8 & 1.1 & 0.5 \\
\hline \multicolumn{13}{|c|}{ Glacial Lake Chicago nearshore sediments from southwestern Muskegon County } \\
\hline M-9 & 150 & 302.8 & 167.8 & 635.4 & 3.788 & 3.4 & 2.6 & 12.7 & 69.1 & 11.8 & 0.3 & 0.1 \\
\hline M-10 & 150 & 304.6 & 170.5 & 647.9 & 3.801 & 3.5 & 2.9 & 13.8 & 68.1 & 11.0 & 0.3 & 0.4 \\
\hline M-13 & 150 & 328.4 & 153.4 & 4735 & 30.86 & 22.7 & 3.8 & 13.9 & 43.5 & 14.0 & 1.2 & 0.9 \\
\hline M-14 & 150 & 298.6 & 250.2 & 514.8 & 2.058 & 0.7 & 0.4 & 9.7 & 79.4 & 9.2 & 0.4 & 0.2 \\
\hline M-18 & 150 & 293.5 & 149.9 & 564.5 & 3.765 & 1.5 & 1.7 & 10.4 & 67.1 & 18.6 & 0.5 & 0.2 \\
\hline M-19 & 150 & 324.0 & 162.2 & 2532 & 15.61 & 13.6 & 6.0 & 17.6 & 49.3 & 12.5 & 0.5 & 0.6 \\
\hline M-20 & 150 & 295.4 & 150.3 & 613.9 & 4.085 & 4.4 & 1.7 & 9.4 & 65.8 & 17.6 & 0.7 & 0.6 \\
\hline Mean & - & 306.8 & 172.0 & 1463 & 9.138 & 7.1 & 2.7 & 12.5 & 63.2 & 13.5 & 0.6 & 0.4 \\
\hline $2 \sigma$ & - & 25.7 & 65.6 & 2988 & 19.6 & 15.0 & 3.3 & 5.4 & 23.0 & 6.4 & 0.6 & 0.5 \\
\hline
\end{tabular}

Notes: gr = gravel; $\mathrm{vcs}=$ very coarse sand; $\mathrm{cs}=$ coarse sand; $\mathrm{ms}=$ medium sand; $\mathrm{fs}=$ fine sand; vfs = very fine sand.

${ }^{\text {a }}$ Sorting coefficient $=D_{90} / D_{10}$.

level, this is notable given that sample $\mathrm{HC}-3$ is from a greater depth $(2.45 \mathrm{~m})$ than the other samples.

\section{DISCUSSION}

\section{OSL ages of inland dunes in Ottawa County, Michigan}

Our OSL ages from the two inland dunes (Table 4 and Fig. 8) are significantly older than previously published OSL and radiocarbon ages for middle to late Holocene coastal dunes in the study area (see Figs. 1 and 3A for location of coastal dunes in the study area). This indicates that inland dunes in the study area are not associated with the well-documented period of eolian activity in coastal Michigan that occurred following the fall from Nipissing high stand after $\sim 5500$ cal yr BP (e.g., Loope and Arbogast, 2000; Arbogast et al., 2002a; Hansen et al., 2003, 2006, 2010). Alternatively, our OSL ages indicate that inland dunes in the study area formed during the Pleistocene-Holocene transition.

The soil profiles we describe corroborate our new OSL ages (Figs. 5 and 6). The soils developed on inland dune crests are weakly to moderately developed Spodosols similar to soils developed on lacustrine surfaces underlying the younger coastal dunes at Rosy Mound Natural Area (Arbogast and Loope, 1999). This confirms that our two inland dunes are significantly older than coastal dunes, which are mid- to late Holocene age. Additionally, dunes and soil profiles similar to those in the study area have also been described in the Saginaw Lowland in east-central Lower Michigan (Fig. 1B) (Arbogast et al., 1997; Arbogast and 
Table 3. Radiocarbon ages from the organic material in alluvium of the Pigeon River valley.

\begin{tabular}{|c|c|c|c|c|c|c|c|}
\hline $\begin{array}{l}\text { Sample } \\
\text { number }\end{array}$ & $\begin{array}{c}\text { Laboratory } \\
\text { ID }\end{array}$ & Sample material $^{\mathrm{a}}$ & $\begin{array}{l}\text { Depth } \\
\text { (m) }\end{array}$ & $\begin{array}{c}{ }^{14} \mathrm{C} \text { age } \\
\left({ }^{14} \mathrm{C} \text { yr BP }\right)\end{array}$ & ${ }^{13} \mathrm{C} /{ }^{12} \mathrm{C}$ & $\begin{array}{c}\text { Calibrated range } \\
(2 \sigma \text { cal yr BP })\end{array}$ & $\begin{array}{l}\text { Mean age } \\
\text { (cal yr BP) }\end{array}$ \\
\hline $\mathrm{HC}-8$ & Beta-353048 & Plant fragments & 2.7 & $5680 \pm 30$ & -28.4 & $6400-6500$ & 6450 \\
\hline HC-9 & Beta-353054 & Plant fragments & 2.8 & $5890 \pm 30$ & -27.0 & $6660-6780$ & 6720 \\
\hline HC-10 & Beta-353052 & Plant fragments & 2.7 & $5220 \pm 40$ & -26.8 & $5910-6170$ & 6040 \\
\hline HC-11 & Beta- 353050 & Plant fragments & 2.5 & $5750 \pm 30$ & -28.2 & $6470-6640$ & 6550 \\
\hline PC-1 & Beta-424922 & Wood & 2.3 & $2390 \pm 30$ & -25.3 & $2345-2490$ & 2420 \\
\hline
\end{tabular}

${ }^{\mathrm{a}}$ All accelerator mass spectrometry samples pretreated with acid/alkali/acid washes.

${ }^{\mathrm{b}}$ Radiocarbon calibration uses IntCal09.

Jameson, 1998). Soils developed on these dunes are also Spodosols, or Inceptisols trending toward Spodosols. Dunes in the Saginaw dune field likely formed after the retreat from the Port Huron advance when Glacial Lake Saginaw drained and the lake bed was exposed (Arbogast et al., 1997; Arbogast and Jameson, 1998). This history is very similar to what occurred in the study area.

Radiocarbon ages of Pigeon River valley fill provide additional corroborating evidence and demonstrate the stratigraphic consistency of our OSL ages. The radiocarbon ages are on buried wood and organics from wetland sediment buried $\sim 2.3$ to $2.8 \mathrm{~m}$ below the current floodplain. The calibrated AMS radiocarbon ages of buried organics in the alluvium in the Pigeon River valley vary from 2345 to 6780 cal yr BP (Table 3) demonstrating that the valley was incised before $6780 \mathrm{cal}$ yr BP (Colgan and Stevens, 2016). Colgan and Stevens (2016) interpreted the valley fill sequence at Hemlock Crossing Park (Fig. 3) as indicating valley incision during the Chippewa low stand $(\sim 11,000$ to $9000 \mathrm{cal}$ yr BP), followed by transgression and valley aggradation from $\sim 9000$ to $\sim 5500$ cal yr BP. The buried alluvial organics formed in wetlands during the Lake Nipissing transgression. Because the inland dunes are crosscut by the valley, it is clear that the dunes are older as demonstrated by our new OSL ages. Fluvial terraces in the Pigeon River valley vary from $\sim 3$ to $10 \mathrm{~m}$ above the current level of Lake Michigan and were likely formed during and after the Nipissing transgression. These terraces truncate the inland dunes all along the valley indicating that the dunes are older than the Nipissing high stand $(\sim 5500 \mathrm{cal}$ yr BP). If the dunes were younger, we would expect them to cover these terraces. On the other hand, large coastal dunes have migrated across the valley and partially blocked the mouth of Pigeon Lake, near Lake Michigan.

In summary, our OSL ages, soil profiles, radiocarbon ages, and stratigraphic position and geomorphic setting of inland dunes all demonstrate that inland dunes in the study area formed after the estimated time of drainage of Glacial Lake Chicago after $\sim 13.6 \mathrm{ka}$ and before the Nipissing transgression and high stand at $\sim 5500$ cal yr BP (Table 1). Based on the range of our OSL ages, dune activity probably began during the late Bølling-Allerød after $\sim 13.6 \mathrm{ka}$ and continued as late as the Preboreal event at $\sim 11.5 \mathrm{ka}$. The peak of dune activity occurred during the Younger Dryas event.

\section{Source of inland dune sand}

The source of the inland dune sand must have been locally derived and deflated from the exposed bed of Glacial Lake Chicago, which is composed of poorly sorted, gravelly medium sand (Table 2). Inland dunes in the study area are dominated by fine sand, whereas the larger coastal dunes are dominated by medium sand (Table 2). Support for our hypothesis of deflation of exposed lake sediments is found in the availability of abundant fine sand in the sandy nearshore lacustrine sediments of Glacial Lake Chicago (Table 2). These sandy lacustrine sediments could also be a source for some of the recently recognized loess in southeastern Lower Michigan (Schaetzl et al., 2015).

Table 4. Optically stimulated luminescence analyses for dune samples from Hemlock Crossing and Pigeon Creek County Parks.

\begin{tabular}{|c|c|c|c|c|c|c|c|c|c|c|c|}
\hline $\begin{array}{l}\text { Lab } \\
\text { number }\end{array}$ & $\begin{array}{l}\text { Sample } \\
\text { number }\end{array}$ & $\begin{array}{c}\mathrm{U} \\
(\mathrm{ppm})\end{array}$ & $\begin{array}{c}\text { Th } \\
(\mathrm{ppm})\end{array}$ & $\begin{array}{c}\mathrm{Rb} \\
(\mathrm{ppm})\end{array}$ & $\begin{array}{c}\mathrm{K}_{2} \mathrm{O} \\
\text { (wt.\%) }\end{array}$ & $\begin{array}{c}\text { In situ } \\
\mathrm{H}_{2} \mathrm{O}(\%)\end{array}$ & $\begin{array}{l}\text { Depth } \\
(\mathrm{m})\end{array}$ & $\begin{array}{c}\text { Dose rate } \\
(\mathrm{Gy} / \mathrm{ka})\end{array}$ & $\begin{array}{c}D_{e}(\mathrm{~Gy}) \\
\pm 2 \sigma\end{array}$ & $\begin{array}{l}\text { Aliquots } \\
\text { (n) }\end{array}$ & $\begin{array}{l}\text { Optical age } \\
\quad \pm 2 \sigma\end{array}$ \\
\hline M046 & $\mathrm{HC}-1$ & 0.44 & 1.60 & 31.24 & 1.12 & 3.33 & 1.50 & 1.43 & $17.54 \pm 1.52$ & 17 & $12.2 \pm 1.1$ \\
\hline M047 & $\mathrm{HC}-2$ & 0.43 & 1.60 & 28.92 & 1.02 & 3.38 & 1.30 & 1.34 & $16.41 \pm 2.06$ & 13 & $12.2 \pm 1.6$ \\
\hline M048 & $\mathrm{HC}-3$ & 0.43 & 1.49 & 30.81 & 1.11 & 5.48 & 2.45 & 1.36 & $18.14 \pm 1.35$ & 15 & $13.3 \pm 1.1$ \\
\hline M049 & PC-1 & 0.45 & 1.60 & 27.80 & 0.98 & 3.37 & 1.50 & 1.30 & $15.05 \pm 1.04$ & 21 & $11.6 \pm 0.9$ \\
\hline M050 & PC-2 & 0.54 & 1.95 & 29.09 & 1.04 & 3.60 & 1.25 & 1.40 & $17.19 \pm 1.50$ & 14 & $12.2 \pm 1.1$ \\
\hline M051 & PC-3 & 0.61 & 2.36 & 28.62 & 1.03 & 3.66 & 1.60 & 1.43 & $17.29 \pm 1.75$ & 17 & $12.1 \pm 1.3$ \\
\hline
\end{tabular}




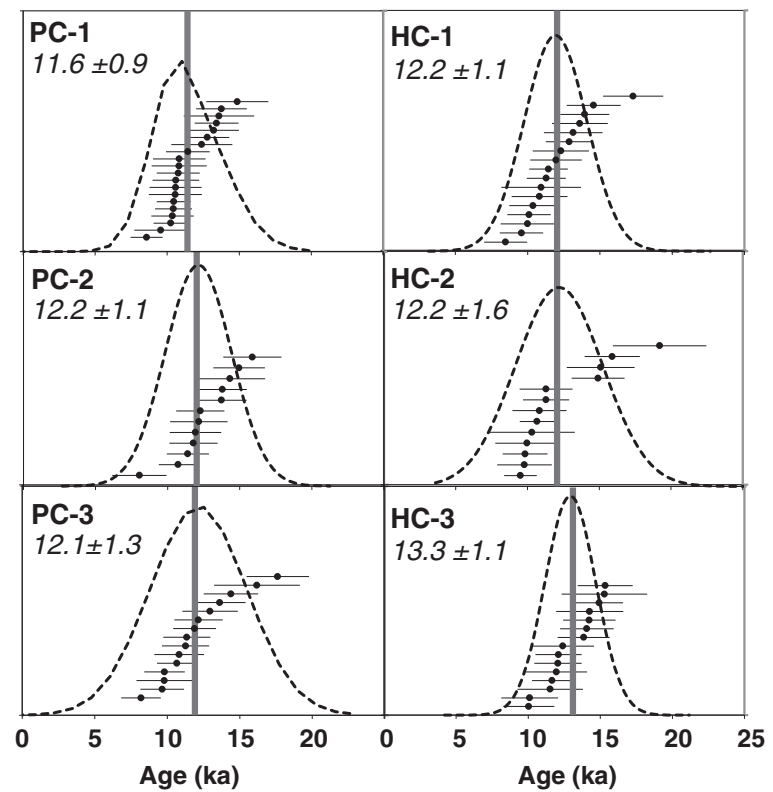

Figure 8. Plots showing ages of multiple aliquots for each sample (black dots), 2-sigma uncertainties (thin lines), and the summed probability distribution of all ages accepted for a given sample (dashed black line).

\section{Inland dune activity in the western Great Lakes region}

Our OSL ages add to a growing number of OSL-dated dune studies that show a peak of eolian dune activity in the western Great Lakes centered at near the end of the Younger Dryas event at the Pleistocene-Holocene transition (Fig. 9). A review of OSL-dated inland dunes located around Lake Michigan (Fig. 9) demonstrates that eolian dune activity and stabilization also peaked slightly after the end of the Younger Dryas event in most of these areas (Figs. 10 and 11). These studies and our new data provide a total of 57 OSL age analyses whose mean is centered on the Pleistocene-Holocene transition (Rawling et al., 2008; Campbell et al., 2011; Kilibarda and Blockland, 2011; Arbogast et al., 2015). We assumed (as the original authors did) that all of our probability density distributions represented single events, except for the ages of Campbell et al. (2011), which both the authors and we assume record at least two dune-forming events.

Rawling et al. (2008) provided 24 OSL ages for eolian dune activity in the Central Sand Plain of Wisconsin, which formed after Glacial Lake Wisconsin drained at $\sim 15,000$ cal yr BP. These OSL ages range from $19.3 \pm 1.7$ to $5.8 \pm 0.4 \mathrm{ka}$. The peak of the probability density distribution of their ages is $\sim 11.5 \mathrm{ka}$, and the arithmetic mean and 1 standard deviation is $11.8 \pm 2.7 \mathrm{ka}$ (Fig. 10). This peak correlates with the end of the Younger Dryas event (Fig. 11). Rawling et al. (2008) proposed three different hypotheses to explain eolian activity and dune stabilization: (1) aridity caused by a climate event, (2) deflation of outwash in the Wisconsin River valley, and (3) melting of permafrost developed on the lake plain, which lowered water tables enabling deflation. They found the most attractive hypotheses to be deflation of outwash or melting of

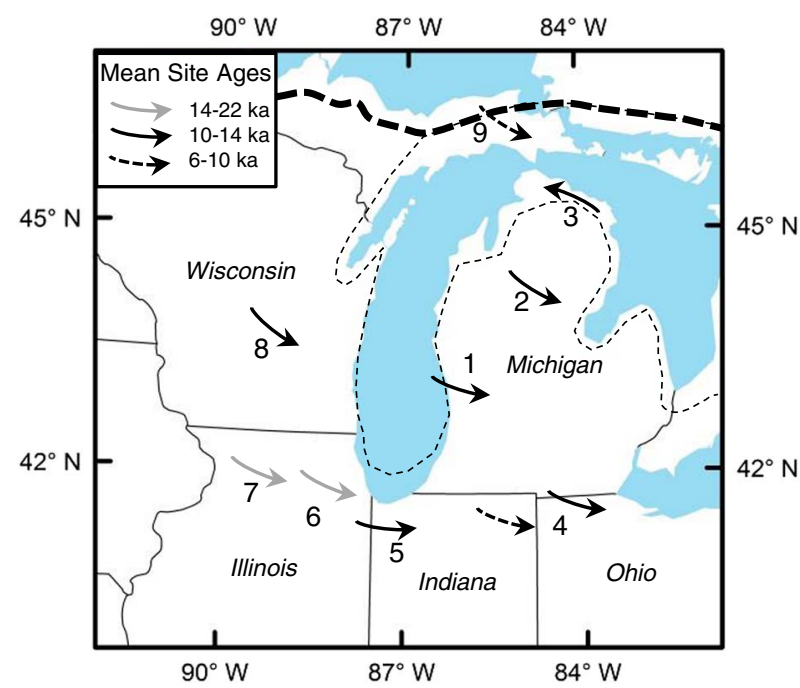

Figure 9. (color online) Location of late Pleistocene to early Holocene dune fields in the western Great Lakes region. Arrows indicate the approximate reconstructed wind directions and age ranges in each study. Thick dashed line is the approximate terminus of the retreating Laurentide Ice Sheet at $\sim 12.9 \mathrm{ka}$ and during the main phase of Glacial Lake Algonquin, which is shown with the thin dotted line (after fig. 5 of Arbogast et al., 2015). (1) Ottawa County, Michigan, dune field (this study). (2) Roscoe dune field of north-central Lower Michigan (Arbogast et al., 2015). (3) Coastal spits cited by Krist and Schaetzl (2001) as evidence for easterly winds along the front of the retreating Laurentide Ice Sheet. (4) Dune fields of northeastern Indiana and northwestern Ohio (Campbell et al., 2011). (5) Dune fields of northwestern Indiana (Kilibarda and Blockland, 2011). (6) Green River Lowland of northwestern Illinois (Miao et al., 2010). (7) Dunes and elongated ice-walled lake plains used by Allred et al. (2014) to reconstruct paleowind directions at $\sim 17,000 \mathrm{cal}$ yr BP. (8) Central Sand Plain of Wisconsin (Rawling et al., 2008). (9) Early Holocene dunes in Upper Michigan (Loope et al., 2010).

permafrost, which then lowered water tables and led to enhanced eolian deflation. This hypothesis is attractive because the peak of the ages occurs at the end of the Younger Dryas event, a time when the climate was changing from cool and dry to a warmer and wetter climate of the early Holocene. Dune activity during the Younger Dryas was then followed by dune stabilization once Holocene climate conditions were established after $\sim 11.7 \mathrm{ka}$ and surfaces became stabilized by vegetation cover.

Campbell et al. (2011) examined inland dunes in northeastern Indiana and northwestern Ohio (Fig. 9) and provided 10 OSL ages that range between $14.1 \pm 1.0$ and $8.8 \pm 0.5 \mathrm{ka}$ (excluding a single young age of $0.79 \pm 0.1 \mathrm{ka}$ ). These 10 OSL ages have two peaks in the probability density distribution, one at $\sim 12.5 \mathrm{ka}$ and another at $\sim 9.0 \mathrm{ka}$ (Fig. 10). They suggested that eolian activity on susceptible deflation surfaces was enhanced during the cooler and drier Younger Dryas event and the subsequent Preboreal oscillation and can be used to compliment pollen records of climate, which also suggest cooler and drier conditions at this time (Campbell et al., 2011). 


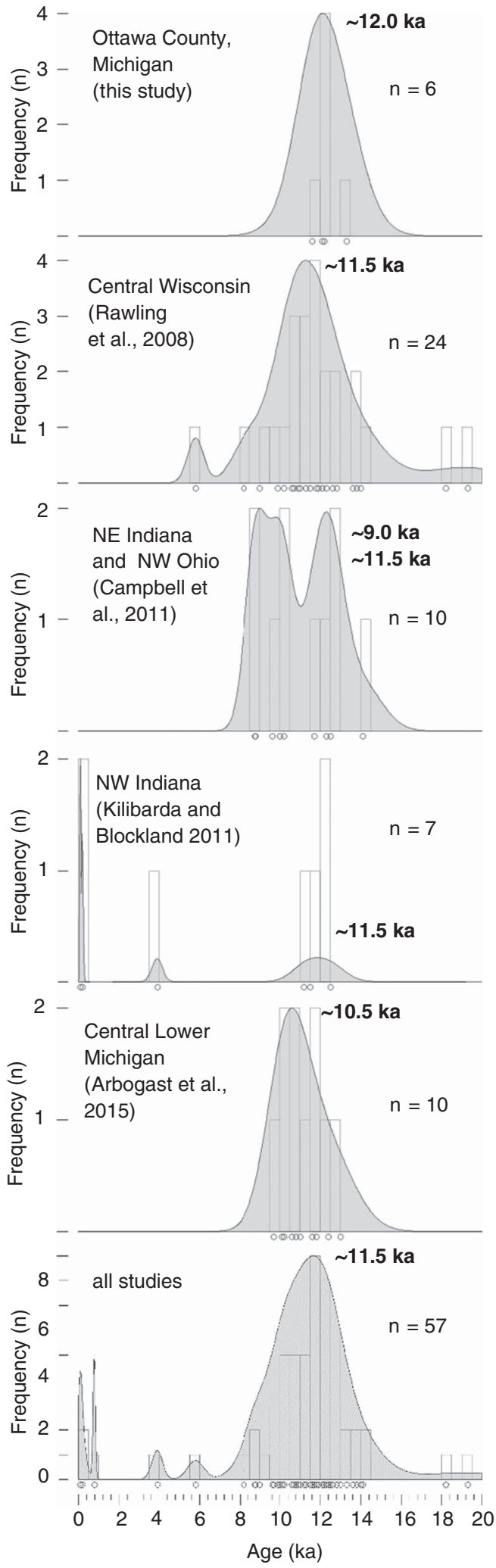

Figure 10. Probability density and histogram plots for dune fields formed between $\sim 14$ and $10 \mathrm{ka}$ (see Fig. 9 for site locations). The circles under the plots are individual sample means. The $y$-axis is number of samples in histograms, and the x-axis is ka before present. Ages correspond to approximate peaks in probability density function plots. The plots were constructed using DensityPlotter v. 7.1 (Vermeesch, 2012).
Inland dunes of the Fair Oaks dune field in northeastern Indiana (Fig. 9) yielded four OSL ages ranging from 12.5 to $11.2 \mathrm{ka}$ (Kilibarda and Blockland, 2011). These dunes also yielded three much younger OSL ages less than 4 ka that they interpreted as reflecting late Holocene reworking. Excluding the three younger ages, the probability density distribution shows a peak at $\sim 11.5 \mathrm{ka}$ and mean and standard deviation of $11.9 \pm 0.6 \mathrm{ka}$ (Figs. 10 and 11). Kilibarda and Blockland (2011) argue that their observations and OSL ages indicate dune building began during the Bølling-Allerød event when easterly and northeasterly winds, attributable to anticyclonic circulation over the retreating ice sheet, formed transverse and barchan dune ridges. This dune-building event was then followed by reworking of the dunes during the Younger Dryas event by westerly winds that formed a great variety of parabolic dunes.

Most recently, Arbogast et al. (2015) provide 10 OSL ages for eolian dune activity in the Rosco dune field of central Lower Michigan (Figs. 1B and 9). These OSL ages range from $13.0 \pm 1.2$ to $9.7 \pm 0.8 \mathrm{ka}$. The peak of the probability density distribution is $\sim 10.5 \mathrm{ka}$, with a mean and standard deviation of $11.1 \pm 1.0 \mathrm{ka}$ (Fig. 10). This peak occurs slightly after the Preboreal oscillation (Fig. 11). The probability density distribution of all 57 OSL ages including our 6 new ages shows a peak occurring at $\sim 11.5 \mathrm{ka}$ slightly after the end of the Younger Dryas event during the Preboreal oscillation (Figs. 10 and 11).

\section{Climate reconstruction based on pollen and permafrost evidence}

Reconstructions of paleoenvironments and climate of Lower Michigan during the Bølling-Allerød and Younger Dryas events, based on plant macrofossils and pollen from inland lake sediment cores, indicate cool and dry conditions (Hupy and Yansa, 2009). Black spruce (Picea mariana) and sedges were common in low areas because of wet soils attributable to melting buried glacier ice and permafrost, whereas open white spruce (Picea glauca) parklands favored the drier uplands (Hupy and Yansa, 2009). Tundra plants and widespread fossil ice-wedge casts and ice-wedge polygons suggest that tundra vegetation and permafrost were present in eastern Wisconsin up to at least 13,000 cal yr BP (Maher and Mickelson, 1996; Maher et al., 1998, Clayton et al., 2001). Relict ice-wedge polygons found on the abandoned surface of Glacial Lake Saginaw in Lower Michigan also indicate that permafrost formed after lake drainage sometime during the Bølling-Allerød warming event and the subsequent Younger Dryas cooling (Lusch et al., 2009). Cool climate, terrestrial gastropods followed by boreal forest indicate ice-free conditions at the Two Creeks site in eastern Wisconsin and the Cheboygan bryophyte site in northern Lower Michigan during the Bølling-Allerød event (Larson, 2011; Rech et al., 2012). All of these observations suggest that Younger Dryas cooling and drying in an area already affected by permafrost provided a suitable environment for eolian deflation of the 


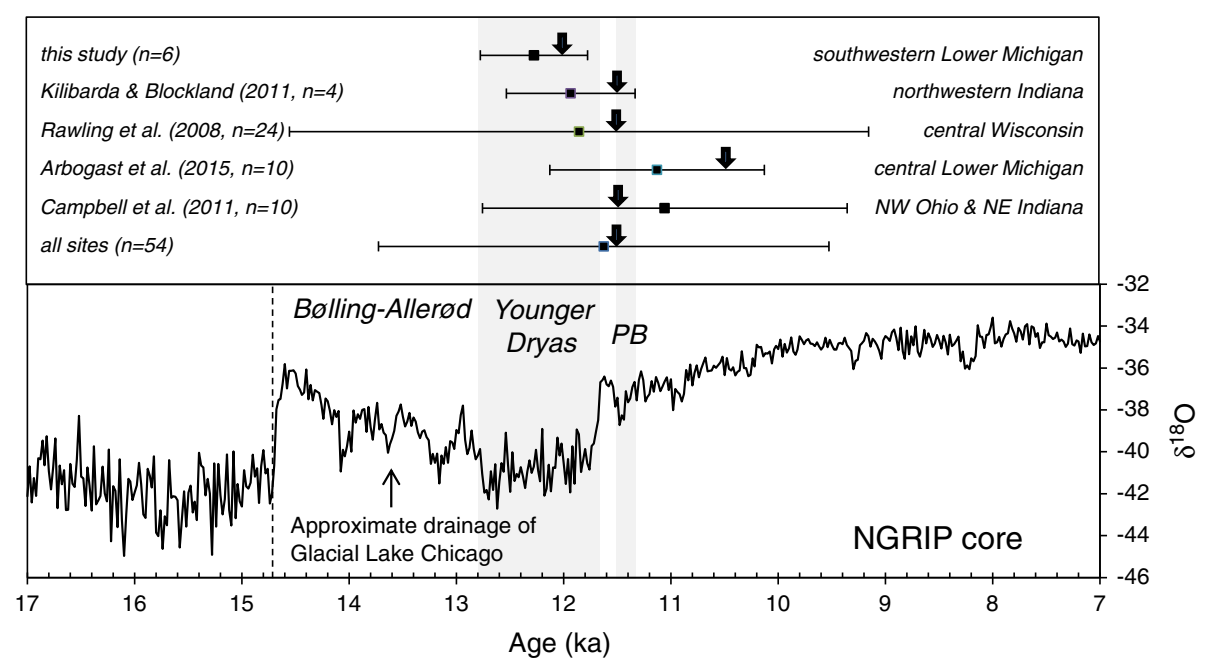

Figure 11. Comparison of dune field mean ages (black squares) to the oxygen isotope record of the North Greenland Ice Sheet Project (NGRIP) ice core. Drainage of Glacial Lake Chicago occurred at 13.6 ka based on the existing radiocarbon chronology (Larson, 2011). Large arrows show peaks of probability density plots determined from Figure 10. Peaks in dune optically stimulated luminescence ages occur during or shortly after the Younger Dryas event and the Preboreal event (PB). Three outlier samples ( $<4$ ka) shown in Figure 9 were not included in the mean for data from Kilibarda and Blockland (2011). One late Holocene outlier ( 0.79 ka) was not included in the mean and standard deviation for data of Campbell et al. (2011).

recently exposed nearshore sediments of Glacial Lake Chicago in the drier uplands of the study area.

\section{Implications for paleolake level history in western Michigan}

Figure 12 illustrates our reconstructions of paleolake levels in the study area (Table 1). Glacial Lake Chicago reached elevations of between $\sim 202$ and $\sim 204 \mathrm{~m}$ amsl, sometime between $\sim 17,000$ and $\sim 15,200$ cal yr BP (Table 1 and Fig. 12A). It is notable that the areas covered by inland dunes in the study area were still covered by Glacial Lake Chicago until after the end of the Calumet Phase at $\sim 13,600$ cal yr BP (Fig. 12), and therefore, dunes could not have been formed before then. Our OSL ages are compatible with this conclusion because our oldest age is $13.3 \pm 1.1 \mathrm{ka}$ and must have formed after drainage of Glacial Lake Chicago, inland of the shorelines of Glacial Lake Algonquin and postglacial Lake Chippewa (Table 1, Fig. 12C). The abandoned bed of Glacial Lake Chicago in the study area was exposed during the Glacial Lake Algonquin and Lake Chippewa levels and up until the present time. Inland dunes formed and stabilized during the Younger Dryas event and perhaps as late as the Preboreal event. During the early Holocene, dunes were stabilized by vegetation and crosscut by erosion of the Pigeon River and other rivers in the study area. The mid-Holocene Nipissing high stand was reached sometime after about $5500 \mathrm{cal}$ yr BP (Baedke and Thompson, 2000). This supports our interpretation that the inland dunes are older than the Nipissing high because terraces in the Pigeon River valley both truncate dunes and do not have dunes on terrace surfaces (Fig. 12C). Most of the large, relatively young coastal dunes lie on the surface flooded by Lake Nipissing and have constricted the Pigeon River by encroachment of dune sand at the river mouth.

\section{Paleowinds in the western Great Lakes region}

Studies in the western Great Lakes region have provided new information on paleowinds reconstructed from OSL-dated inland dunes during the Pleistocene-Holocene transition (Fig. 9). Easterly winds are inferred from spits that developed in glacial Lake Algonquin between $\sim 13.6$ and $11 \mathrm{ka}$ (Krist and Schaetzl, 2001; Vader et al., 2012) and from dunes in northwestern Indiana (Kilibarda and Blockland, 2011). These studies hypothesize that easterly winds were the result of anticyclonic circulation above the retreating Laurentide Ice Sheet as predicted in atmospheric models of late Pleistocene circulation (Kutzbach and Guetter, 1986; Broccoli and Manabe, 1987; COHMAP Members, 1988).

All of the recently OSL-dated inland dune fields cited in the previous section indicate northwesterly and westerly winds during the late part of the Bølling-Allerød, Younger Dryas event, and the Preboreal oscillation (Fig. 9). Undated inland dunes in the Saginaw dune field of Lower Michigan (Fig. 9) also indicate winds from the northwest and west after about 15,000 cal yr BP (Arbogast et al., 1997; Arbogast and Jameson, 1998). The northwesterly and westerly directions confirm previous interpretations that the anticyclonic circulation must have been limited in its effects after the late part of the Bølling-Allerød event and during the Younger Dryas event (Arbogast et al., 2015; Kilibarda and Blockland, 2011). This was also the interpretation of Rawling et al. (2008) for the inland dunes that formed in the Central Sand Plain of Wisconsin as no evidence was found there for easterly winds even though some of these dunes were older than the BøllingAllerød. Arbogast et al. (2015) proposed that there must have been a very steep energy gradient to the winds because easterly wind directions were apparently occurring less than 

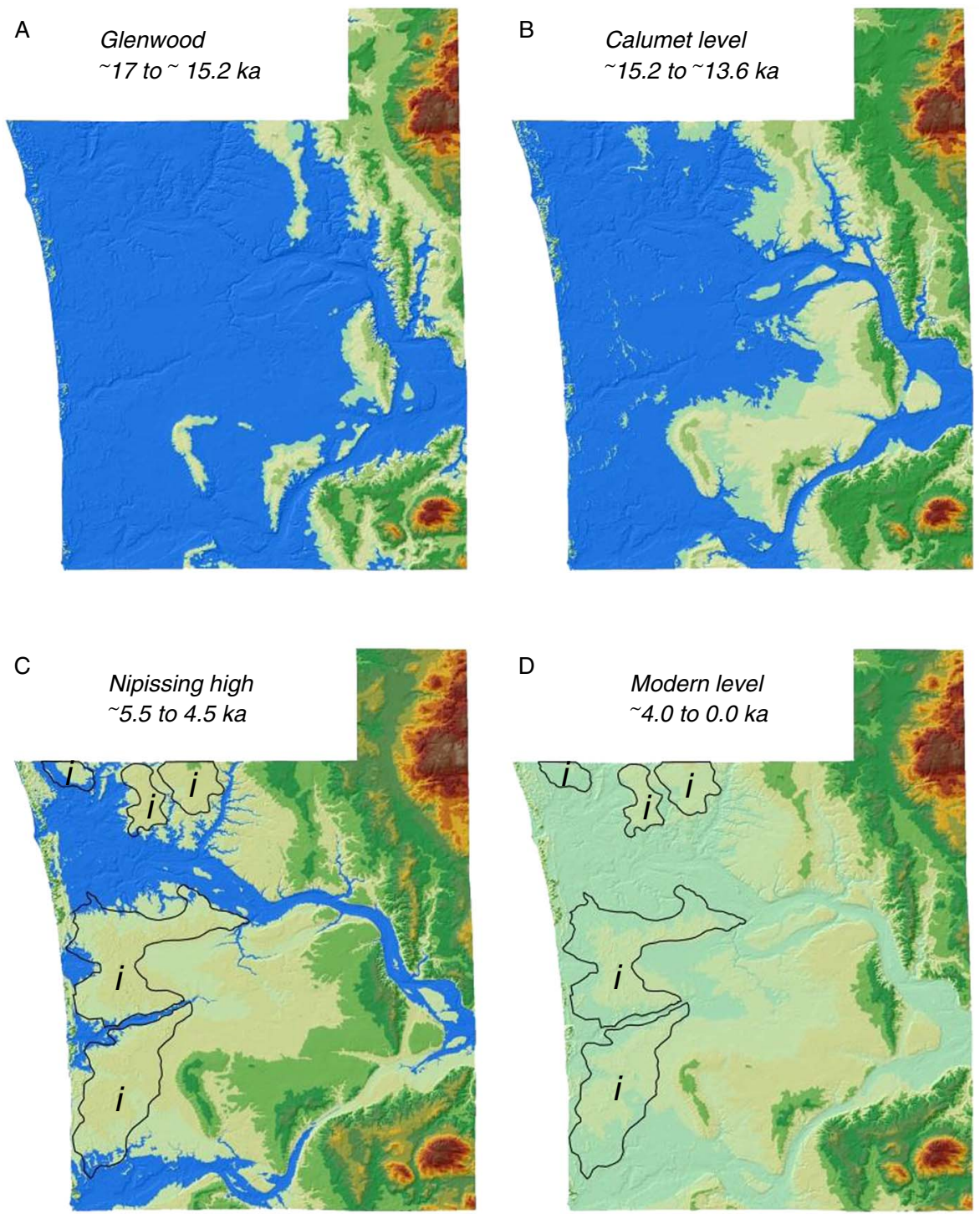

Figure 12. (color online) Time-series reconstructions of lake levels during the late Pleistocene and Holocene mapped using a digital elevation model and estimates of lake levels from landforms and sediments in the county. (A) Glenwood I and II levels of Glacial Lake Chicago ( 203 m amsl). (B) Calumet level of Glacial Lake Chicago ( 195 m amsl). (C) Postglacial Lake Nipissing at its maximum level in Ottawa County ( $\sim 186 \mathrm{~m}$ amsl) and the location of inland parabolic dune fields outlined in fine black lines (i). (D) Modern lake level of Lake Michigan with areas of inland parabolic dune fields outlined with black lines (i). The lake bed of Glacial lake Chicago would have been exposed after the fall from the Calumet level after $\sim 13.6 \mathrm{ka}$ (panel B).

$150 \mathrm{~km}$ from northwesterly winds (Fig. 5 of Arbogast et al., 2015). Our observations provide no evidence for easterly anticyclonic winds nor evidence against a steep energy gradient hypothesis. In summary, inland dunes in this study, and three of four sites with OSL ages reviewed previously, provide no support for anticyclonic easterly and northeasterly winds during the latest part of the Bølling-Allerød event and the subsequent Younger Dryas event.

\section{CONCLUSIONS}

1. Inland dunes are common on the abandoned bed of Glacial Lake Chicago in Ottawa County and surrounding coastal counties in western Lower Michigan. Inland dunes have parabolic forms and are modified by blowouts and human disturbance.

2. Six new OSL ages indicate that inland dunes formed and stabilized between $13.3 \pm 1.1$ and $11.6 \pm 0.9 \mathrm{ka}$ (2-sigma uncertainty). Soils developed on the inland dunes, radiocarbon ages on buried organics in the Pigeon River valley, and stratigraphic and landform relationships all corroborate our OSL ages.

3. The inland dunes in the study area formed and stabilized after drainage of Glacial Lake Chicago at $\sim 13,600 \mathrm{cal} \mathrm{yr}$ BP during the late Bølling-Allerød, Younger Dryas, and Preboreal events.

4. The source of inland dune sand was the gravelly, medium to fine nearshore sand on the abandoned bed of Glacial Lake Chicago. Sand was deflated by northwesterly and 
westerly winds, before vegetation was able to completely stabilize sandy nearshore lake sediments.

5. Four other OSL-dated dune fields in the western Great Lakes region also show that eolian activity driven by northwesterly and westerly winds was a widespread phenomenon during the Pleistocene-Holocene transition. This supports a hypothesis that changing climatic conditions at the Pleistocene-Holocene transition and the availability of recently deglaciated surfaces provided an ideal environment for eolian activity.

6. Evidence of northwesterly and westerly winds at all of these sites supports previous interpretations of the limited effect of an anticyclone developed over the retreating Laurentide Ice Sheet.

\section{ACKNOWLEDGEMENTS}

Funding to undergraduate student Sara Thurkettle was provided by a Norman and Helen Gibson Summer Scholarship for summer of 2015 (Grand Valley State University). We thank lead park naturalist Kristen Hintz and Ottawa County Parks for access to sites in Pigeon Creek and Hemlock County Parks. Tom Valachovics, Andrew Alder, and Alexander Rarick helped with field sampling. Nick Colaianne shared grain-size data from Kirk Park. Grand Valley State University undergraduates Spencer Brower, Reece Elling, Natalie Renkes, Mike Moon, and students in P.C.'s winter 2016 geophysics class helped collect and process the GPR data from Pigeon Creek Park. J. Teller and an anonymous reviewer provided useful comments to help focus and improve the manuscript.

\section{Supplementary material}

To view supplementary material for this article, please visit https://doi.org/10.1017/qua.2016.13

\section{REFERENCES}

Allred, K., Luo, W., Konen, M., Curry, B.B., 2014. Morphometric analysis of ice-walled lake plains in Northern Illinois: Implications of lake elongation by wind-induced dual-cycle currents. Geomorphology 220, 50-57.

Arbogast, A.F., 2009. Sand dunes. In: Schaetzl, R.., Darden, J., Brandt, D. (Eds.), Michigan Geography and Geology. Pearson, Boston, pp. 274-287.

Arbogast, A.F., Bigsby, M.E., DeVisser, M.H., Langley, S.A., Hanson, P.R., Daly, T.A., Young, A.R., 2010. Reconstructing the age of coastal sand dunes along the northwestern shore of Lake Huron in Lower Michigan: paleoenvironmental implications and regional comparisons. Aeolian Research 2, 83-92.

Arbogast, A.F., Hansen, E.C., Van Oort, M.D., 2002a. Reconstructing the geomorphic evolution of large coastal dunes along the southeastern shore of Lake Michigan. Geomorphology 46, 241-255.

Arbogast, A.F., Jameson, T.P., 1998. Age estimates of inland dunes in east-central Lower Michigan using soils data. Physical Geography 19, 485-501.

Arbogast, A.F., Loope, W.L., 1999. Maximum-limiting age of Lake Michigan coastal dunes: their correlation with Holocene lake level history. Journal of Great Lakes Research 25, 372-382.
Arbogast, A.F., Luehmann, M.D., Miller, B.A., Wernette, P.A., Adams, K.M., Waha, J.D., O’Neil, G.A., et al. 2015. LatePleistocene paleowinds and aeolian sand mobilization in northcentral Lower Michigan. Aeolian Research 16, 109-116.

Arbogast, A.F., Scull, P., Schaetzl, R.J., Harrison, J., Jameson, T.P., Crozier, S., 1997. Concurrent stabilization of some interior dune fields in Michigan. Physical Geography 18, 63-79.

Arbogast, A.F., Wintle, A.G., Packman, S.C., 2002b. Widespread middle Holocene dune formation in the eastern Upper Peninsula of Michigan and the relationship to climate and outlet-controlled lake level. Geology 30, 55-58.

Baedke, S.J., Thompson, T.A., 2000. A 4,700-year record of lake level and isostasy for Lake Michigan. International Association of Great Lakes Research 26, 416-426.

Blott, S.J., Pye, K., 2001. GRADISTAT: a grain size distribution and statistics package for the analysis of unconsolidated sediments. Earth Surface Processes and Landforms 26, 1237-1248.

Blumer, B.E., Arbogast, A.F., Forman, S.L., 2012. The OSL chronology of eolian sand deposition in a perched dune field along the northwestern shore of Lower Michigan. Quaternary Research 77, 445-455.

Bretz, J.H., 1951. The stages of Lake Chicago: their causes and correlations. American Journal of Science 249, 410-429.

Broccoli, A.J., Manabe, S., 1987. The influence of continental ice, atmospheric $\mathrm{CO}_{2}$, and land albedo on the climate of the last glacial maximum. Climate Dynamics 1, 87-99.

Buol, S.W., Hole, F.D., McCraken, R.J., 1989. Soil Genesis and Classification. Iowa State University Press, Ames.

Campbell, M.C., Fischer, T.G., Goble, R.J., 2011. Terrestrial sensitivity to abrupt cooling recorded by aeolian activity in northwest Ohio, USA. Quaternary Research 75, 411-416.

Clayton, L., Attig, J.W., Mickelson, D.M., 2001. Effects of late Pleistocene permafrost on the landscape of Wisconsin, USA. Boreas 30, 173-188.

COHMAP (Cooperative Holocene Mapping Project) Members, 1988. Climatic changes of the last 18,000 years: observations and model simulations. Science 241(4869), 1043-1052.

Colgan, P.M., Stark, J.M., 2005a. Quaternary Geology of the Muskegon East 7.5 Minute Quadrangle. Scale 1:24,000. Open File Report. Michigan Department of Environmental Quality, Lansing.

Colgan, P.M., Stark, J.M., 2005b. Quaternary Geology of the Muskegon West 7.5 Minute Quadrangle. Scale 1:24,000. Open File Report. Michigan Department of Environmental Quality, Lansing.

Colgan, P.M., Stevens, B.S., 2016. Radiocarbon and sedimentary evidence for the Nipissing transgression ( 7000 to 6000 years ago) at Hemlock Crossing County Park, Ottawa County, Michigan. Michigan Academician 43, 75-76.

Colgan, P.M., Tort, C., 2006. Quaternary Geology of the Sullivan 7.5 Minute Quadrangle, Michigan. Scale 1:24,000. Open File Report. Michigan Department of Environmental Quality, Lansing.

Colgan, P.M., Vanderlip, C.A., Braunschneider, K.M., 2015. Athens Subepisode (Wisconsin Episode) non-glacial and older glacial sediments in the subsurface of southwestern Michigan, USA. Quaternary Research 84, 382-397.

Cooke, R.U., Warren, A., Goudie, A.S., 1993. Desert Geomorphology. UCL Press, London.

Cunningham, A., Wallinga, J., 2010. Selection of integration time intervals for quartz OSL decay curves. Quaternary Geochrono$\log y$ 5, 657-666.

Curry, B.B., Grimley, D.A., McKay, E.D., 2011. Quaternary glaciations in Illinois. In: Ehlers, J., Gibbard, P.L., Hughes, P.D. (Eds.), Quaternary Glaciations - Extent and Chronology: A 
Closer Look. Developments in Quaternary Science. Elsevier Science, Amsterdam, pp. 467-487.

Durcan, J.A., Duller, G.A.T., 2011. The fast ratio: a rapid measure for testing the dominance of the fast component in the initial OSL signal from quartz. Radiation Measurements 46, 1065-1072.

Durcan, J.A., King, G.E., Duller, G.A.T., 2015. DRAC: dose rate and age calculator for trapped charge dating. Quaternary Geochronology 28, 54-61.

Farrand, W.R., 1982. Quaternary Geology of Michigan. Scale 1:500,000. Michigan Department of Environmental Quality, Lansing.

Galbraith, R., Roberts, R., Laslett, G., Yoshida, H., Olley, J., 1999. Optical dating of single and multiple grains of quartz from Jinmium Rock Shelter, northern Australia: Part I, experimental design and statistical models. Archaeometry 41, 339-364.

Guerin, G., Mercier, N., Adamiec, G., 2011. Dose-rate conversion factors: update. Ancient TL 29, 5-8.

Hansel, A.K., Mickelson, D.M., 1988. A reevaluation of the timing and causes of high lake phases in the Lake Michigan basin. Quaternary Research 29, 113-128.

Hansel, A.K., Mickelson, D.M., Schneider, A.F., Larsen, C.E., 1985. Late Wisconsinan and Holocene history of the Lake Michigan basin. In: Karrow P.F., Calkin, P.E. (Eds.), Quaternary Evolution of the Great Lakes. Geological Association of Canada, Special Paper 30, 39-53.

Hansen, E.C., Arbogast, A.F., Packman, S.C., Hansen, B., 2003. Post-Nipissing origin of a backdune complex along the southeastern shore of Lake Michigan. Physical Geography 23, 233-244.

Hansen, E.C., Arbogast, A.F., van Dijk, D., Yurk, B., 2006. Growth and migration of parabolic dunes along the southeastern coast of Lake Michigan. Journal of Coastal Research SI39, 209-214.

Hansen, E.C., Fisher, T.G., Arbogast, A.F., Bateman, M.D., 2010. Geomorphic history of low-perched, transgressive dune complexes along the southeastern shore of Lake Michigan. Aeolian. Research 1, 111-127.

Hupy, C.M., Yansa, C.H., 2009. The last 17,000 years of vegetation history. In: Schaetzl, R., Darden, J., Brandt, D. (Eds.), Michigan Geography and Geology. Pearson, Boston, pp. 91-105.

Kilibarda, Z., Blockland, J., 2011. Morphology and origin of the Fair Oaks Dunes in NW Indiana, USA. Geomorphology 125, 305-318.

Kincare, K.A., 2007. Response of the St. Joseph River to lake level changes during the last 12,000 years in the Lake Michigan basin. Journal of Paleolimnology 37, 383-394.

Kincare, K.A., Larson, G.J., 2009. Evolution of the Great Lakes. In: Schaetzl, R., Darden, J., Brandt, D. (Eds.), Michigan Geography and Geology. Pearson, Boston, pp. 174-190.

Krist, F. Jr., Schaetzl, R.J., 2001. Paleowind (11,000 BP) directions derived from late spits in northern Michigan. Geomorphology 38, $1-18$.

Kutzbach, J.E., Guetter, P.J., 1986. The influence of changing orbital parameters and surface boundary-conditions on climate simulations for the past 18,000 years. Journal of Atmospheric Science 43, 1726-1759.

Larson, G.J., 2011. Ice-margin fluctuations at the end of the Wisconsin Episode, Michigan, USA. In: Ehlers, J., Gibbard, P.L., Hughes, P.D. (Eds.), Quaternary Glaciations - Extent and Chronology: A Closer Look. Developments in Quaternary Science. Elsevier Science. Amsterdam, pp. 489-497.

Larson, G.J., Schaetzl, R.J., 2001. Origin and evolution of the Great Lakes. Journal of Great Lakes Research 27, 518-546.

Leverett, F., Taylor, F.B., 1915. The Pleistocene of Indiana and Michigan and the History of the Great Lakes. US Government Printing Office, Washington, DC.
Lewis, D.W., McConchie, D., 1994. Practical Sedimentology. Chapman and Hall, New York.

Loope, H.M., Loope, W.L., Goble, R.J., Fisher, T.G., Jol, H.M., Seong, J.C., 2010. Early Holocene dune activity linked with final destruction of glacial Lake Minong, eastern Upper Michigan, USA. Quaternary Research 74, 73-81.

Loope, W.L., Arbogast, A.F., 2000. Dominance of an 150-year cycle of sand-supply change in late Holocene dune-building along the eastern shore of Lake Michigan. Quaternary Research 54, 414-422.

Loope, W.L., Loope, H.M., Goble, R.J., Fisher, T.G., Lytle, D.E., Legg, R.J., Wysocki, D.A., Hansen, P.R., Young, A.R., 2012. Drought drove forest decline and dune building in eastern upper Michigan, USA, as the upper Great Lakes became closed basins. Geology 40, 315-318.

Lusch, D.P., Stanley, K.E., Schaetzl, R.J., Kendall, A.D., Van Dam, R.L., Nielsen, A., Blumer, B.E., et al. 2009. Characterization and mapping of patterned ground in the Saginaw lowlands, Michigan: possible evidence for late-Wisconsin permafrost. Annals of the Association of American Geographers 99, 1-22.

Maher, L.J., Mickelson, D.M., 1996. Palynological and radiocarbon evidence for deglaciation events in the Green Bay Lobe, Wisconsin. Quaternary Research 46, 251-259.

Maher, L.J. Jr., Miller, N.G., Baker, R.G., Curry, B.B., Mickelson, D.M., 1998. Paleobiology of the sand beneath the Valders diamicton at Valders, Wisconsin. Quaternary Research 49, 208-221.

Martin, H.M., 1955. Map of the Surface Formations of the Southern Peninsula of Michigan. Scale 1:500,000. Michigan Geological Survey Division Publication 49. Department of Conservation, Geological Survey Division, Lansing, MI.

Miao, X.D., Hanson, P.R., Wang, H., Young, A.R., 2010. Timing and origin for sand dunes in the Green River Lowland of Illinois, upper Mississippi River valley, USA. Quaternary Science Reviews 29, 763-773.

Murray, A.S., Wintle, A.G., 2000. Luminescence dating of quartz using an improved single-aliquot regenerative-dose protocol. Radiation Measurements 32, 57-73.

Rawling, J.E. III, Hanson, P.R., Young, A.R., Attig, J.W., 2008. Late Pleistocene dune construction in the Central Sand Plain of Wisconsin, USA. Geomorphology 100, 494-505.

Rech, J.A., Nekola, J.C., Pigati, J.S., 2012. Radiocarbon ages of terrestrial gastropods extend duration of ice-free conditions at the Two Creeks forest bed, Wisconsin, USA. Quaternary Research 77, 289-292.

Schaetzl, R.J., Luehmann, M.D., Peter, B., Connallon, C., Smidt, S. J., Liu, W., Kincare, K.A., Walikowiak, T., Thorlund, E., Holler, M., 2015. Spatial and textural analysis of soils confirm loess mantle on outwash plains of southwestern Michigan. Geological Society of America, Abstracts with Programs 47(5), 21.

US Department of Agriculture, Soil Conservation Service. 1972. Soil Survey of Ottawa County, Michigan. US Government Printing Office, Washington, DC.

Vader, M.J., Zeman, B.K., Schaetzl, R.J., Anderson, K.L., Walquist, R.W., Freiberger, K.M., Emmendorfer, J. A., Wang, H., 2012. Proxy evidence for easterly winds in Glacial Lake Algonquin, from the Black River delta in northern Lower Michigan. Physical Geography 33, 252-268.

Vermeesch, P., 2012. On the visualization of detrital age distributions. Chemical Geology 312-313, 190-194.

William Martinus \& Associates. 2000. Lower Pigeon River Greenway, Ottawa County, Michigan: A Natural Features Inventory. William Martinus \& Associates, West Olive, MI. 